\title{
Review Article \\ Synthesis Approaches of Zinc Oxide Nanoparticles: The Dilemma of Ecotoxicity
}

\author{
Ayesha Naveed U1 Haq, ${ }^{1}$ Akhtar Nadhman, ${ }^{1,2}$ Ikram Ullah, ${ }^{1}$ Ghulam Mustafa, \\ Masoom Yasinzai, ${ }^{1}$ and Imran Khan ${ }^{1}$ \\ ${ }^{1}$ Sulaiman Bin Abdullah Aba Al-Khail Centre for Interdisciplinary Research in Basic Sciences (SA-CIRBS), \\ International Islamic University, Islamabad, Pakistan \\ ${ }^{2}$ Institute of Integrative Biosciences, CECOS University, Peshawar, Pakistan
}

Correspondence should be addressed to Akhtar Nadhman; shamsnazman@gmail.com and Imran Khan; i.khan@iiu.edu.pk

Received 19 January 2017; Accepted 14 March 2017; Published 18 April 2017

Academic Editor: Mohamed Bououdina

Copyright (c) 2017 Ayesha Naveed Ul Haq et al. This is an open access article distributed under the Creative Commons Attribution License, which permits unrestricted use, distribution, and reproduction in any medium, provided the original work is properly cited.

Human's quest for innovation, finding solutions of problems, and upgrading the industrial yield with energy efficient and costeffective materials has opened the avenues of nanotechnology. Among a variety of nanoparticles, zinc oxide nanoparticles ( $\mathrm{ZnO}$ ) have advantages because of the extraordinary physical and chemical properties. It is one of the cheap materials in cosmetic industry, nanofertilizers, and electrical devices and also a suitable agent for bioimaging and targeted drug and gene delivery and an excellent sensor for detecting ecological pollutants and environmental remediation. Despite inherent toxicity of nanoparticles, synthetic routes are making use of large amount of chemical and stringent reactions conditions that are contributing as environmental contaminants in the form of high energy consumption, heat generation, water consumption, and chemical waste. Further, it is also adding to the innate toxicity of nanoparticles (NPs) that is either entirely ignored or poorly investigated. The current review illustrates a comparison between pollutants and hazards spawned from chemical, physical, and biological methods used for the synthesis of $\mathrm{ZnO}$. Further, the emphasis is on devising eco-friendly techniques for the synthesis of $\mathrm{ZnO}$ especially biological methods which are comparatively less hazardous and need to be optimized by controlling the reaction conditions in order to get desired yield and characteristics.

\section{Introduction}

Nanoparticles (NPs) have revolutionized all major industrial areas, from drug delivery to agriculture and food industry [1]. Chemical synthesis methods for NPs include emulsion solvent extraction method, double emulsion and evaporation method, salting out method, emulsion diffusion method, and solvent displacement/precipitation method. But, industrial scale production of NPs has familiarized a new kind of pollution into environment. It is highly desirable to reduce the loads of chemical pollution on environment by developing new and convenient methods to overcome the drawbacks of chemical methods, improve the yield, and reduce the cost [2].

Bulk zinc oxide is cost-effective and shows a variety of applications in industry including nanoparticle synthesis $[3,4]$. $\mathrm{ZnO}$ nanoparticles are II-VI semiconductor with wide band gap energy, that is, $3.3 \mathrm{eV}$, and high excitation energy, that is, $60 \mathrm{eV}$. Thus, it can tolerate large electric fields, high temperature, and high power operations [5]. These properties make it highly applicable in solar cells, photo catalysis, and chemical sensors [6-12]. Moreover, it can also be made conductive by doping [13]. ZnO nanocrystals predominantly show wurtzite construction with lattice parameters $a=$ $0.3296 \mathrm{~nm}$ and $c=0.52065 \mathrm{~nm}$. $\mathrm{ZnO}$ in its simplest form shows tetrahedron geometry in which each ion is enclosed by four counter ions pointing towards corners of a tetrahedron (Table 1). This tetrahedron configuration is responsible for the piezoelectricity and pyroelectricity [14, 15]. Piezoelectricity of $\mathrm{ZnO}$ arises from its crystal structure and makes it applicable for acoustic wave resonators and acoustic-optic modulators. Also, because of its Centro symmetric structure, it is the highest tensor among all semiconductors and gives large electromechanical coupling [5]. 
TABLE 1: Physical properties of $\mathrm{ZnO}$ nanoparticles.

\begin{tabular}{lc}
\hline $\begin{array}{l}\text { Physical appearance } \\
\text { Crystalline structure }\end{array}$ & White, colorless, odorless solid \\
Molecular Weight & Wurtzite \\
Electron effective mass & $81.38 \mathrm{~g} / \mathrm{mol}$ \\
Melting Point & 60 \\
Density & $1,975^{\circ} \mathrm{C}$ \\
Isoelectric point & $5.47 \mathrm{~g} / \mathrm{cm}^{2}$ \\
Space group & $9.5-10$ \\
Standard molar entropy & $C_{6 \mathrm{v}}{ }^{4}-P_{3} \mathrm{mc}^{-1}$ \\
Standard enthalpy of formation & $43.9 \mathrm{~J} \cdot \mathrm{K}^{-1} \mathrm{~mol}^{-1}$ \\
\hline
\end{tabular}

\section{Importance of $\mathrm{ZnO}$ for Industries}

Ultraviolet A and Ultraviolet B radiations from the sun can cause injury by free radical mechanism on skin cells. $\mathrm{ZnO}$ nanoparticles of size less than $200 \mathrm{~nm}$ have high efficiency in scattering light and induce cosmetically desired whitening to the skin. It has also been used in foot care, ointments, and over-the-counter topical products [16-21]. Singh and Nanda performed a detailed comparative study between conventional zinc oxide and nanosized $\mathrm{ZnO}$ particles for their sun screen efficiency. Good texture, better spreadability, and enhanced in vitro sun protection factor (SPF) proved the advantageous role of nanoparticles in cosmetics [22]. Hypothesized hazards to human health due to these nanoparticles are still unexplored and it would be counterproductive to avoid them without any evidence.

Another astonishing property of $\mathrm{ZnO}$ is the green luminescence, related to the point defects, which makes it a useful agent for bioimaging. This can be further enhanced by doping with transition elements, for example, copper, cobalt, and nickel, for more desirable optical properties. Other application of $\mathrm{ZnO}$ includes gene delivery that is considered as an important milestone in therapeutics and has attained much attention of the researchers for the treatment of diseases like severe combined immune deficiency (ADA-SCID), chronic granulomatous disorder (CGD), hemophilia, genital blindness, lysosomal storage disease and muscular dystrophy, neurodegenerative diseases, viral infections (e.g., influenza, HIV, and hepatitis), heart disease, and diabetes. Quantum dots and tetrapod like structures of $\mathrm{ZnO}$ have been explored extensively for such applications [23-25]. Such quantum dots are also playing a vital role as sensors. $\mathrm{ZnO}$ is a semiconductor and its properties can be altered by a number of ways that has made it an exciting candidate for the sensor exploration. Such sensors have indispensable role, that is, from detecting environmental pollutants to epidemic diseases outbreaks. A number of authors have reported $\mathrm{ZnO}$ based biosensors for sensing cholesterol, biochemistry of enzymes, and other biosensing applications [26, 27]. Kazemi and coauthors have synthesized $\mathrm{ZnO}$ by sol-gel and hydrothermal method and devised a home-built apparatus which responded best at its "working temperature" to sense ethanol. Adsorbed oxygen species trapped the electron creating a charge depleted layer supposed to be responsible for sensing properties of the created sensor [28]. In another study, Liu and coscientists reported a high performance $\mathrm{ZnO}$ based sensor for $\mathrm{n}$-butanol sensing. Low temperature solvothermal method gave highly crystalline wurtzite NPs (spherical in shape with diameter of $8.4 \pm 1.3 \mathrm{~nm}$ ). The fabricated sample had the ability to sense n-butanol up to $500 \mathrm{ppm}$ with a recovery time of 22 seconds. The designed sensor exhibited several advantages such as high and fast response, short recovery time, and good stability towards n-butanol gas [29].

Nowadays, $\mathrm{ZnO}$ has been widely investigated for plant protection products, fertilizers, soil improvement, water purification, and many other [3, 30-33]. Antimicrobially active packaging is a new generation of nano-food packaging based on metal nanocomposites which are made by incorporating $\mathrm{ZnO}$ into polymer films [34-38]. Espitia et al., has reviewed the utility of $\mathrm{ZnO}$ nanoparticles in food preservation and packaging industry when applied to biodegradable polymeric metrics. The NPs improved the quality of food and packaging mainly by three mechanisms, that is, release of antimicrobial ions, damaging the integrity of bacterial cell, and the formation of ROS by the effect of light radiation [39]. Elmer and White have reported the pesticidal properties of the $\mathrm{ZnO}$. They sprayed synthesized $\mathrm{ZnO}$ on tomato and eggplant. It was noted that $\mathrm{ZnO}$ reduced disease estimate by $28 \%$ when compared to the control [40]. On the basis of thermodynamics, $\mathrm{ZnO}$ should dissolve faster and to a greater extent than bulk $\mathrm{ZnO}$ particles (equivalent spherical diameter $>100 \mathrm{~nm}$ ). These novel solubility features of $\mathrm{ZnO}$ might be exploited to improve the efficiency of $\mathrm{Zn}$ fertilizers. Milani et al. found that urea and MAP granules coated with $\mathrm{ZnO}$ showed more thermodynamic dissolution may be due to $\mathrm{pH}$ difference; however kinetics of $\mathrm{Zn}$ dissolution remained unaffected [41].

\section{Toxicity of ZnO in Mammalian Model}

However, controversial results have been reported in the literature regarding toxicity of the $\mathrm{ZnO}$ in the living cells particularly in mammalian cells. Some of the reports have shown that $\mathrm{ZnO}$ are biocompatible and nontoxic [42-44], while some studies have recently reported both in vivo and in vitro toxicity of the $\mathrm{ZnO}$ on mammalian cells [45-48]. It can be elucidated from such studies that the toxicity of $\mathrm{ZnO}$ depends upon the concentration used. Vandebriel and Jong had reviewed the $\mathrm{ZnO}$ toxicity in mammalian model [48]. For more study, refer to reviews of [49-51]. Further, such toxicity is important in other aspects, for example, for the treatment of cancerous, pathogenic, and leukemic T cells [52-58]. Such nanoparticles are also important to overcome problems like drug resistance which is one of the major problem in the pharmaceutical industry [59]. This is because of the nonselectivity of $\mathrm{ZnO}$.

\section{Fabrication of ZnO Nanoparticles for Different Applications}

A variety of synthetic techniques are used for the synthesis of $\mathrm{ZnO}$. These techniques broadly can be divided into three types, that is, chemical, biological, and physical methods 


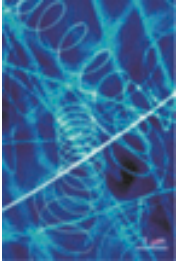

(a)

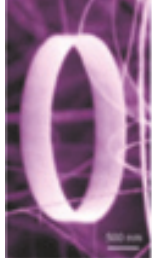

(b)

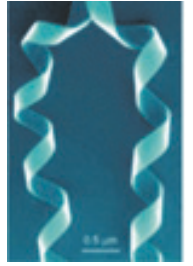

(c)

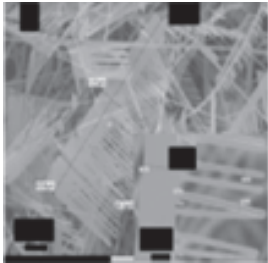

(d)

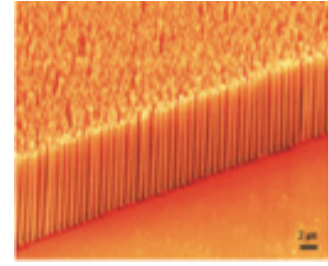

(e)

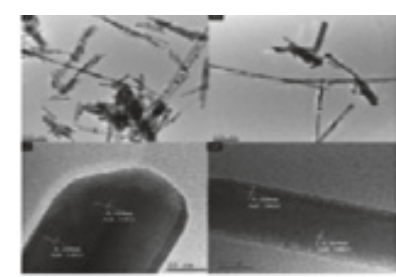

(f)

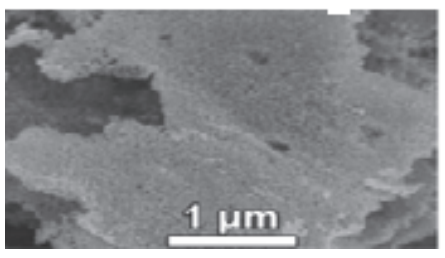

(g)

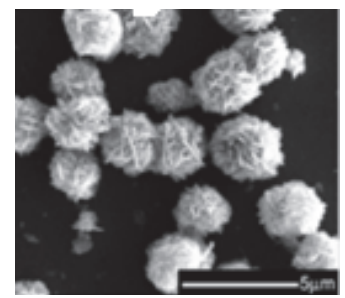

(k)

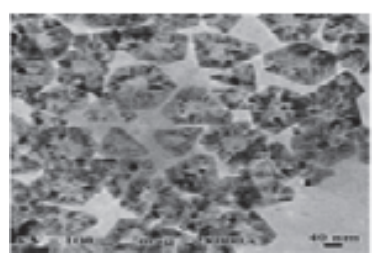

(h)

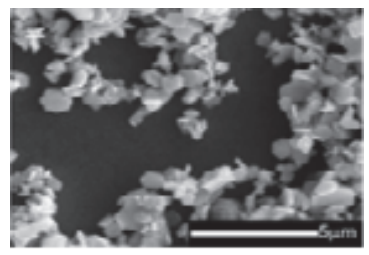

(i)

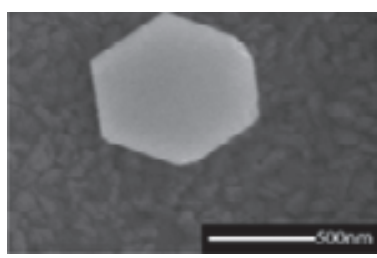

(j)

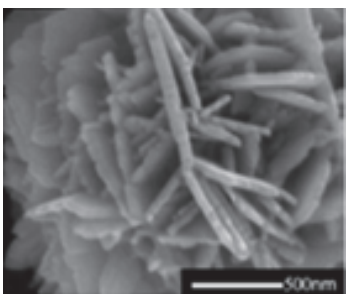

(1)

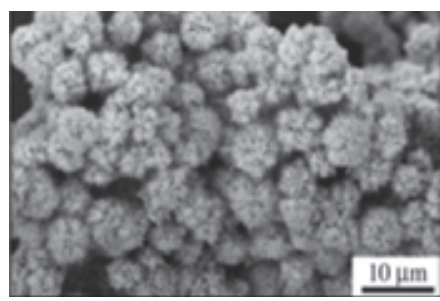

(m)

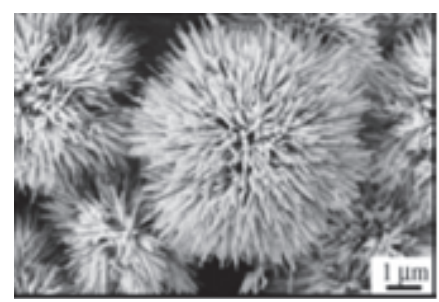

(n)

FIgURE 1: Different structures of ZnO; one-dimensional ZnO: (a) nanosprings, (b) nanorings, (c) nanohelix, (d) nanocombs, (e) nanowires, and (f) nanorods (adopted from [89, 90]). Two-dimensional $\mathrm{ZnO}$; (g) nanosheets, (h) nanopellets, and (i) nanoplates (adopted from [91-93]). Three-dimensional ZnO; (k) \& (l) nanoflowers. (m) Nanomesosphere. (n) Nanourchins (adopted from [91, 94]).

(Figures 1 and 2). Chemical synthesis can further be divided into liquid phase synthesis and gas phase synthesis. Liquid phase synthesis includes precipitation, coprecipitation method, colloidal methods, sol-gel processing, water-oil microemulsions method, hydrothermal synthesis, solvother$\mathrm{mal}$, and sonochemical, and polyol method. And vapor phase fabrication includes pyrolysis and inert gas condensation methods.

4.1. Liquid Phase Synthesis. In a typical precipitation and coprecipitation method, a reducing agent (mostly inorganic alkalis) is allowed to react with the zinc salt. A resultant soluble or insoluble precipitate is produced that is afterwards washed and calcined at different temperatures to obtain the particular nanoparticles with desired morphology and characteristics. A range of nanoparticles and reaction conditions are used to control the size and shape of the $\mathrm{ZnO}$ by this method [60]. Colloidal methods rely on the simplest and well established chemistry since antiquity. However, in literature it was first reported by Faraday in 1857, who synthesized colloids of gold nanoparticles by the reduction of $\mathrm{HAuCl}_{4}$ with phosphorus. Sol-gel techniques rely on colloidal chemistry. Sols are referred to the colloidal solution consisting of solid particles suspended in liquid phase having a diameter of a few hundred nanometers. Gels are mostly formed by polycondensation or polyesterification methods followed by aging to achieve phase transformations and Ostwald ripening. The gels are dehydrated at temperature as high as $8000^{\circ} \mathrm{C}$ and finally densified at temperature greater than $8000^{\circ} \mathrm{C}$ to obtain metal oxide nanoparticles. An advantage of solgel methods is the insurance of highly pure and uniform structured $\mathrm{ZnO}$ [61]. Formation of thorn like $\mathrm{ZnO}$ in solgel method was reported by Khan and companions. The method was a little modified by mechanical stirring. Zinc acetate dihydrate $\left[\mathrm{Zn}\left(\mathrm{CH}_{3} \mathrm{COO}\right)_{2} \cdot 2 \mathrm{H}_{2} \mathrm{O}\right]$, sodium hydroxide $(\mathrm{NaOH})$, and $\mathrm{CTAB}$ were used as precursors. Obtained nanoparticles were less than $50 \mathrm{~nm}$ which showed significant antimicrobial activity [61].

In solvothermal and hydrothermal processes, originators are dissolved in hot solvents (other than water) or water under moderate to high pressure (1-10,000 atm) and moderately high to high temperature $\left(100-1000^{\circ} \mathrm{C}\right)$. These processes are used to synthesize a variety of zinc nanostructures such as thin films, bulk powders, spheres (3D), rods (2D), and wires (1D). Further, this method is also useful for the synthesis of metastable and thermodynamically stable $\mathrm{ZnO}$ via manipulation of the reaction conditions [62]. In a study, the solvothermal synthesis of single layer $\mathrm{ZnO}$ was reported by Rai et al. They aimed to investigate the effect of zinc salts on the morphology of NPs. Formation of NPs in a range of $100-150 \mathrm{~nm}$ and $20-25 \mathrm{~nm}$ length occurred, respectively, whereas NPs were $20-25 \mathrm{~nm}$ in diameter. The synthesized nanorods also showed more sensitivity towards $\mathrm{NO}_{2}$ [63].

4.2. Gas Phase Synthesis. One of the highly used techniques is spray pyrolysis method, in which aerosol droplets of the 


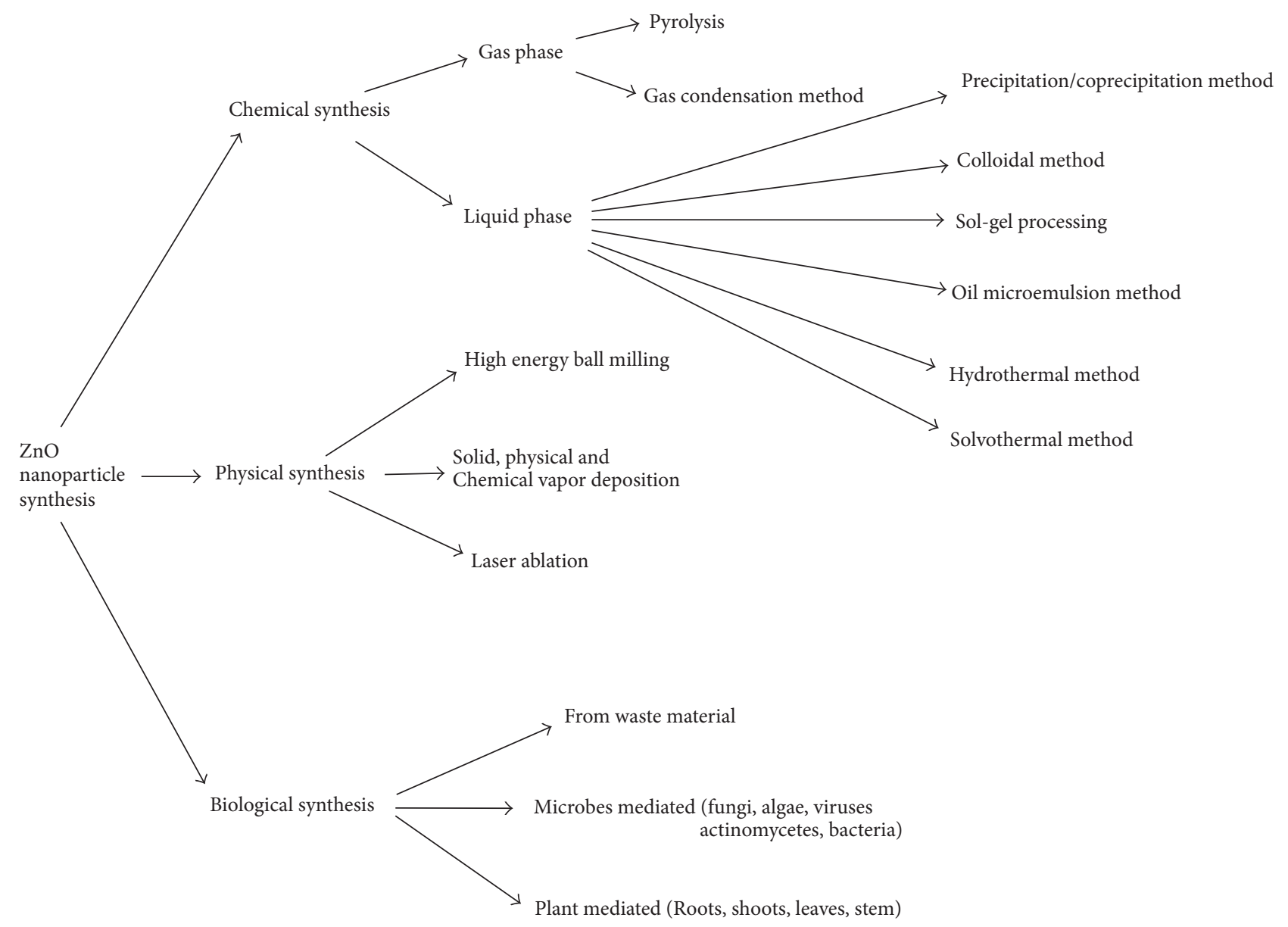

FIgURE 2: Major synthetic techniques used for $\mathrm{ZnO}$ nanoparticles synthesis.

precursor zinc salt are produced via flame heating. The droplets are dispersed in the gas and their size is reduced by dehydration. The last steps involve the decomposition and sintering of the required material [64]. Another method is inert gas condensation methods that is subdivided into physical vapor deposition (without catalytic interaction) and chemical vapor deposition (with catalytic interaction). Principally, these methods comprise evaporation of zinc source inside a chamber by resistive heat. Different sources of heat such as electron or laser beams or radio frequencies are also used. From the heat chamber, the vapors are forced to migrate into cooler chamber having inert gas, from where they are collected for further consolidation. The major disadvantage of this method is the coalesces and agglomeration of $\mathrm{ZnO}$ nanoparticles. Another important method is the one-step levitational gas condensation method that was reported by $\mathrm{Uhm}$ and coworkers for $\mathrm{ZnO}$. Apparatus consisted of $2.5 \mathrm{~kW}$ induction generator levitation and evaporation chamber and oxygen concentration control unit. Obtained nanoparticles showed very good morphology with diameter of $30 \mathrm{~nm}$ [65].

4.3. Physical Methods. Physical methods of $\mathrm{ZnO}$ nanoparticles synthesis include high energy ball milling, melt mixing, physical vapor deposition, laser ablation, sputter deposition, electric arc deposition, and ion implantation. In most physical/mechanical processes, the production rates of $\mathrm{ZnO}$ nanoparticles are very high and are mostly used for the industrial processes. High energy ball milling is a nonequilibrium process developed by Salah and coworkers in 1961. In this method powdered material placed inside a ball mill is subjected to high energy collision from balls [66]. Amirkhanlou and coscientists reported high energy ball milling processes as very efficient, cost-effective, and simple techniques for the preparation of $\mathrm{ZnO}$ nanostructures. They used 15 balls with diameter of $20 \mathrm{~mm}$ confined in a $500 \mathrm{ml}$ bowl. XRD and field emission scanning electron microscopy (FESEM) showed $\mathrm{ZnO}$ nanopowder particles with crystallite size of $15 \mathrm{~nm}$, particle size of about $60 \mathrm{~nm}$, and lattice strain of $0.67 \%$. Similar methodology was reported by Salah et al. and used such $\mathrm{ZnO}$ in antimicrobial activity [66]. Laser ablation technique utilizes a laser beam to remove particle from a solid or a liquid surface. Spherical $\mathrm{ZnO}$ with average diameter of $35 \mathrm{~nm}$ was reported by Ismail and companions. They used pulsed laser ablation in double distilled water [67]. At lower reflux, materials are heated by the energy absorbed through laser and evaporates, while, at higher refluxes, materials may convert into plasma. Other frequently and studied methods used are vapor solid liquid (VLS), physical vapor deposition (PVD), and chemical vapor deposition (CVD) [68]. Physical vapor deposition (PVD) methods are used 

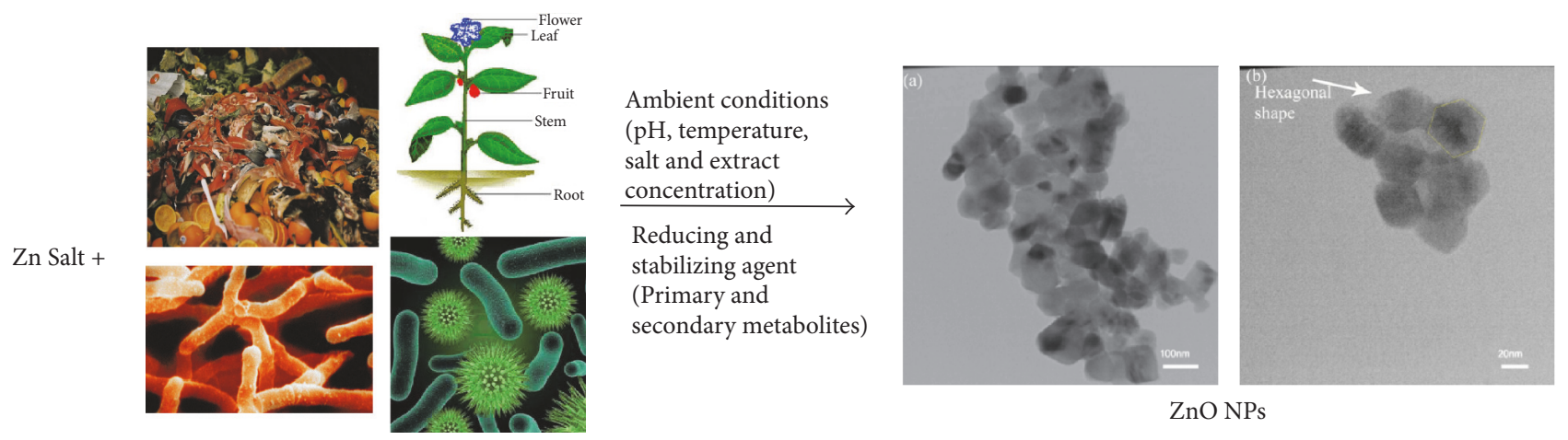

Figure 3: Green synthesis of $\mathrm{ZnO}$ via plants, microbes, and other routes.

to coat the surfaces by depositing the metals. Two types of techniques, namely, evaporation and sputtering, are used in PVD. Sputtering refers to the mechanism of particle escape from the surface by striking high energy particles. The ions for sputtering process are supplied from plasma [39].

4.4. Green Synthesis of Nanoparticles. Green routes are used for the synthesis of $\mathrm{ZnO}$ because of the least possible number of chemicals utilized that produces least amount of pollutants and are energy efficient as well as cost-effective. A number of natural moieties such as plants, fungi, algae, bacteria, and viruses are used to synthesize the $\mathrm{ZnO}$ (Figure 3).

4.4.1. Plant Mediated Synthesis. Plants and plant extracts as a machinery for metal nanoparticles synthesis are fascinating as they eliminate the need of using hazardous materials as well as the tedious process of culturing and downstream processing. However, plant extracts are more attractive because the methodology is much simpler and cost-effective $[69,70]$. Nanoparticles synthesis driven by plant extracts is perhaps the most explored biological source. Plants have the ability to synthesize the nanoparticles both via in vivo and in vitro methods. The mechanism of synthesis of such nanoparticles by plants is their capability to uptake metals from the soil and water, hyperaccumulation, and further reduction to recoverable nanoparticles. Such techniques are extensively used in phytoremediation and phytomining. However, the focus is majorly on silver and gold nanoparticles on using plants. Literature is limited in the synthesis of $\mathrm{ZnO}$ by plant and plant extract based routes.

In vitro approaches make use of plant extracts to bioreduce a particular zinc salt (zinc nitrate, sulphate, chloride, and many other) and provide a control over size and shape of the nanoparticles. Basically, plants contain a number of primary and secondary metabolites, for example, tannins, terpenoids, saponins, starches, polypeptides, flavonoids, and phenolic, that act as an excellent reducing as well as capping agents. Mild solvents like water, ethanol, or methanol are used for the extraction of the plant metabolites, which are allowed to react with zinc salt solution under different conditions to obtain a maximum yield [71-73].
4.4.2. Microorganisms Facilitated Synthesis of Nanoparticles. Microbes are considered as eco-friendly factories of nanoparticles synthesis. Interactions between metals and microbes have been exploited for various biological applications in the fields of bioremediation, biomineralization, bioleaching, and biocorrosion [74]. It is one of the most sustainable, ecofriendly techniques so far in spite of its few limitations. Both prokaryotes and eukaryotes are used for the synthesis of metal/metal oxide especially $\mathrm{ZnO}$. Further, the synthesis may be intracellular or extracellular.

Fungi are decomposers as well as parasite in nature. In intracellular synthesis, fungal biomass is incubated for a particular time period in dark along with a zinc salt solution, while in extracellular synthesis fungal filtrates are treated with the precursor solution and synthesis is assessed [75]. A number of studies are available on using fungi as $\mathrm{ZnO}$ synthesizer. Jain et al. isolated 19 fungal cultures from rhizopheric soil. Among those cultures, Aspergillus aeneus isolate NJP12 showed highest potential for extracellular synthesis of $\mathrm{ZnO}$ under ambient conditions. The resultant nanoparticles were coated with protein which acted as a stabilizer [76]. In another study, fungal filtrate of Aspergillus niger was used by Jacob and coscientists for the production of the $\mathrm{ZnO}$. The synthesized nanoparticles were spherical in shape with an average diameter of 39.4-114.6 nm [77]. Baskar and coworkers extracellularly prepared $\mathrm{ZnO}$ by Aspergillus terreus filtrate. The synthesized $\mathrm{ZnO}$ particles were spherical in shape with a size range of 54.8 to $82.6 \mathrm{~nm}$ [78].

However, a number of studies are also available on using bacteria as green synthesizer for $\mathrm{ZnO}$; for example, bacterial strain Aeromonas hydrophila formed spherical and oval shaped nanoparticles with an average diameter of $57.72 \mathrm{~nm}$ [79]. Synthetic pathways of nanoparticles by microbes may involve basic combinations of cellular biochemistry, metal ions transportations in and out of the cells, microbial resistance towards toxic metal mechanism and activated metal-binding sites, intracellular metal ions accumulation, and metal oxide nucleation [80]. Lactobacillus sporogenes was reported to produce $\mathrm{ZnO}$ of diameter of 5-15 $\mathrm{nm}$. The authors proposed the mechanism of synthesis that depends upon reduction of metals by oxidoreductases which were activated by the nutritional media contents and $\mathrm{pH}$ variations [81]. Actinomycetes, having properties of both prokaryotes 
(fungi) and bacteria, are also used for the synthesis of $\mathrm{ZnO}$ particles. Scientists are attempting to develop an eco-friendly and cost-effective method, for example, by using brown marine macroalgae Sargassum muticum aqueous extract. The resulting nanoparticles had diameter ranging from 30 to $57 \mathrm{~nm}$ and hexagonal wurtzite in structure [82].

4.4.3. Other Green Synthesis Methods. A number of other green means are used for the synthesis of $\mathrm{ZnO}$. Jha and Prasad have reported the formation of $\mathrm{ZnO}$ by slaughtered goat waste (mainly intestine). Simple distillation method by methanol followed by boiling with zinc chloride salt was adopted. This resulted in agglomerates of nanoparticles as smaller as 3-11 nm. His work is an important contribution in getting rid of waste which subsequently may cause disease dispersal [83]. Researchers have also explored the $\mathrm{ZnO}$ synthetic capability of the peels obtained from different fruits and vegetables. Mishra and Sharma used fresh peels extract powder of Punica granatum. Distilled water was used to prepare the extract, which was mixed with zinc nitrate solution at $60-80^{\circ} \mathrm{C}$ under constant stirring. In another study, filtrate of Musa balbisiana peels and zinc nitrate dihydrate was used to obtain $\mathrm{ZnO}$ NPs by Tamuly and coworkers. Nanoflowers of less than $2 \mathrm{~nm}$ in diameter were obtained which were used as catalyst for the synthesis of chalcone derivatives [84-88].

\section{Environmental Implications of Physical, Chemical, and Green Synthesis}

5.1. Capping Agents, Surfactants, and Stabilizers. Three major factors should be kept in view while devising an industrial scale synthesis of the nanoparticles. These factors are solvent choice, the use of an environmentally benign reducing agent, and the use of a nontoxic material for nanoparticle stabilization [95]. In chemical synthesis, capping agents and stabilizers are extensively used in order to control the size and to avoid agglomeration [96]. Owning to the wide application of the $\mathrm{ZnO}$ nanoparticles and their large production, potential of capping agents and stabilizers are investigated by many researchers. Despite inherent toxicity, organic and polymeric capping agents are majorly contributing in environmental pollution. Toxicity of the surface modified and unmodified $\mathrm{ZnO}$ on zebra fish were comprehensively studied by the Zhou and his colleagues. Their experiment showed a significant difference in toxicity level of surface modified and unmodified $\mathrm{ZnO}$ NPs [97]. Toxicity of some of the frequently used capping and stabilizing agents is mentioned in Table 2.

5.2. Reducing Agents and $p H$. Most of the synthetic techniques for $\mathrm{ZnO}$ utilize a reducing agent to reduce a respective zinc salt and vigorous synthetic environment that involves either highly acidic or basic conditions. Precipitation/coprecipitation is the easiest and widely employed method for the $\mathrm{ZnO}$ synthesis. This method mainly employs sodium hydroxide $(\mathrm{NaOH})$ as reducing agent, which is highly corrosive and degrades all kinds of protein. Dissolution of $\mathrm{NaOH}$ in water is exothermic and may cause heat burns or may ignite. On contact with metals it produces flammable hydrogen. In the synthesis of $\mathrm{ZnO}$, excessive amounts of $\mathrm{NaOH}$ with higher molar concentrations are used to ensure the reaction completion. Upon filtration of reaction mixture, supernatant is discarded that might directly go to waste water and ultimately in water bodies. It not only may degrade the metallic parts of the sewage system but also alters the $\mathrm{pH}$ of water bodies causing hazards to aquatic flora and fauna.

Another highly used chemical for $\mathrm{ZnO}$ synthesis is hydrazine, which is a highly reactive alkali and reducing agent extensively used in industry and military. Strict protective instrument utilization is recommended while working with hydrazine. It may cause burns to skin and severely damages the respiratory track while overexposure may cause death. Due to its corrosive potential and its reactivity with oxidant, it is of great ecological concern. Metabolites of hydrazine have more ability to damage than the parent compound [98, 99]. Ethanol is known to be therapeutic in low to moderate dosage; however, high dosage or chronic exposures may lead to dehydration, central nervous system suppression, impaired sensory and motor function, slowed cognition, unconsciousness, and possible death [100-102]. Ethylene glycol shares a number of characteristics. In earlier stage of metabolism, it is responsible for the metabolic acidosis of intoxication. In late stages, lactate may also accumulate, mainly due to formate inhibition of the respiratory chain. However, toxicity of ethylene glycol is complex and not fully understood yet [103]. High concentrations of 1,3 propandiol in lab rats have shown significant toxicity [81].

5.3. Sonication. Sonicators use ultrasonic or sound energy to agitate the particles in the mixture. Typical lab sonicators employ $20 \mathrm{kHz}$ of ultrasonic frequency. The major hazards associated with the use of sonicator are the creation of hearing impairment and generation of aerosols [104]. Sonochemical synthesis of $\mathrm{ZnO}$ nanoparticles has been recently reported by many groups [105-111]. Two types of aerosols are produced by the sonochemical method, namely, chemical aerosols produced by the reagents used in the method and aerosols of nanoparticles. Moreover, the aerosols produced by the chemicals often go unattended in the labs. Furthermore, there is no such report to understand the mechanism of NP aerosols. However, Taurozzi's groups emphasized on the optimization and standardization of sonological parameters. They recommended the rational use of the sonicator and comprehending the unattended side effects [112].

5.4. Temperature. Anthropogenic accomplishments using high temperature processes are altering the overall heat balance of the earth; that is, it is increasing the entropy. The major disadvantage of the high temperature processes is the consumption of the energy. Majorly, heat evolving from high temperature processes may cause heat edema, heat rashes, heat cramps, heat exhaustion, heat syncope, and heat strokes [113]. A number of methods in synthesis of $\mathrm{ZnO} \mathrm{NP}$ involve high temperatures, for example, hybrid electrochemical thermal method $\left(60-700^{\circ} \mathrm{C}\right)$ [114], gas condensation method $\left(595^{\circ} \mathrm{C}\right)$ [115], direct thermal decomposition method $\left(600^{\circ} \mathrm{C}\right)$ [116], spray pyrolysis method $\left(1200^{\circ} \mathrm{C}\right)$ [117], and high 
TABLE 2: Frequently employed capping agents and stabilizers.

\begin{tabular}{|c|c|c|c|}
\hline Capping agents/stabilizers & Inherent toxicity & $\begin{array}{l}\text { Toxicity } \\
\text { reported by }\end{array}$ & $\begin{array}{l}\text { Reference of } \\
\text { utility in } \mathrm{ZnO} \\
\text { NP synthesis }\end{array}$ \\
\hline Triethyl amine & $\begin{array}{l}\text { Reversible } \\
\text { ocular effects including corneal swelling and halo vision in } \\
\text { humans }\end{array}$ & [119] & $\begin{array}{l}{[120]} \\
{[121]} \\
{[122]}\end{array}$ \\
\hline Oleic acid & $\begin{array}{l}\text { Promote apoptosis and necrosis, mitochondrial } \\
\text { depolarization, lipid accumulation, and overexpression of } \\
\text { C-MYC and P53 }\end{array}$ & {$[123]$} & $\begin{array}{l}{[124]} \\
{[125]} \\
{[126]}\end{array}$ \\
\hline Thioglycerol & $\begin{array}{l}\text { Irritant for skin, eye and inhalation; Hazardous in case of } \\
\text { ingestion }\end{array}$ & {$[127]$} & $\begin{array}{l}{[128]} \\
{[129]} \\
{[130]}\end{array}$ \\
\hline EDTA & Cytotoxic and genotoxic & $\begin{array}{l}{[131]} \\
{[132]}\end{array}$ & $\begin{array}{l}{[133]} \\
{[134]} \\
{[135]}\end{array}$ \\
\hline Tetraethyl ammoniumbromide & $\begin{array}{l}\text { Tremors, incoordination, flaccid prostration, and death } \\
\text { from respiratory failure in animals }\end{array}$ & [136] & $\begin{array}{l}{[137]} \\
{[138]} \\
{[139]}\end{array}$ \\
\hline Tetraethyl orthosilicate & Highly damaging to eyes & {$[140]$} & $\begin{array}{l}{[141]} \\
{[142]} \\
{[143]}\end{array}$ \\
\hline Polyethylene glycol (PEG) & Immunogenic & [144] & $\begin{array}{l}{[11]} \\
{[145]} \\
{[137]}\end{array}$ \\
\hline Polyethylene phthalate (PEP) & Endocrine disruptor & [146] & $\begin{array}{l}{[147]} \\
{[148]} \\
{[149]}\end{array}$ \\
\hline Ethylene glycol & Adversely affects reproduction and development & [150] & $\begin{array}{c}{[11]} \\
{[151]} \\
{[152]}\end{array}$ \\
\hline Gelatin & Toxic & {$[153]$} & $\begin{array}{l}{[154]} \\
{[155]}\end{array}$ \\
\hline Polyvinyl alcohol (PVA) & Toxic & $\begin{array}{l}{[156]} \\
{[157]}\end{array}$ & $\begin{array}{l}{[158]} \\
{[159]} \\
{[160]}\end{array}$ \\
\hline Polyvinyl pyrrolidine (PVP) & Weight increase in lab mice & {$[161]$} & $\begin{array}{l}{[162]} \\
{[163]} \\
{[164]}\end{array}$ \\
\hline
\end{tabular}

temperature mixing hydrothermal processes $\left(160-200^{\circ} \mathrm{C}\right)$ [118], that might be lethal.

5.5. Toxicological Implications of Green Synthesis of $\mathrm{ZnO}$. Instability of biologically synthesized nanoparticles is worth consideration. Physical instability of nanoparticles may alter their arrangement/confirmations due to different conditions like temperature pressure, light, medium, $\mathrm{pH}$, and so on, which may lead to the creation of the different unwanted chemical moieties. Moreover, potential hazards of these chemical metabolites are very poorly investigated.

Inherent toxicity of $\mathrm{ZnO}$ nanoparticles is linked to dissolution and ROS generation. Dissolution is the leading phenomenon in chemical and biological instability of $\mathrm{ZnO}$. Metal solubility and concentration gradient between particle surface and the bulk solution phase acts as a driving force.
Dissolution of the $\mathrm{ZnO}$ nanoparticles may lead to the $\mathrm{Zn}^{2+}$ and $\mathrm{Zn}(\mathrm{OH})^{+}$that are highly toxic [165]. However, it is possible to control the dissolution phenomenon by coating the nanoparticles, doping, surface area effect, additional factors such as size-dependent changes of the surface curvature, and roughness of the particles. Also, the crystalline nature of the nanoparticles may be changed by redox reaction taking place on the surface of NPs, which may occur at the same time or simultaneously. Electronic transfers taking place during these processes lead to the generation of the reactive oxygen species (ROS) and oxidative stress inducing toxicological injury [166]. Chemically synthesized NPs are considerably stable; still they pose both type of hazards, whereas green synthesized nanoparticles are relatively less stable. Thus, the problem of dissolution of ions and ROS augments which may act as potential threat to the surrounding environment. 


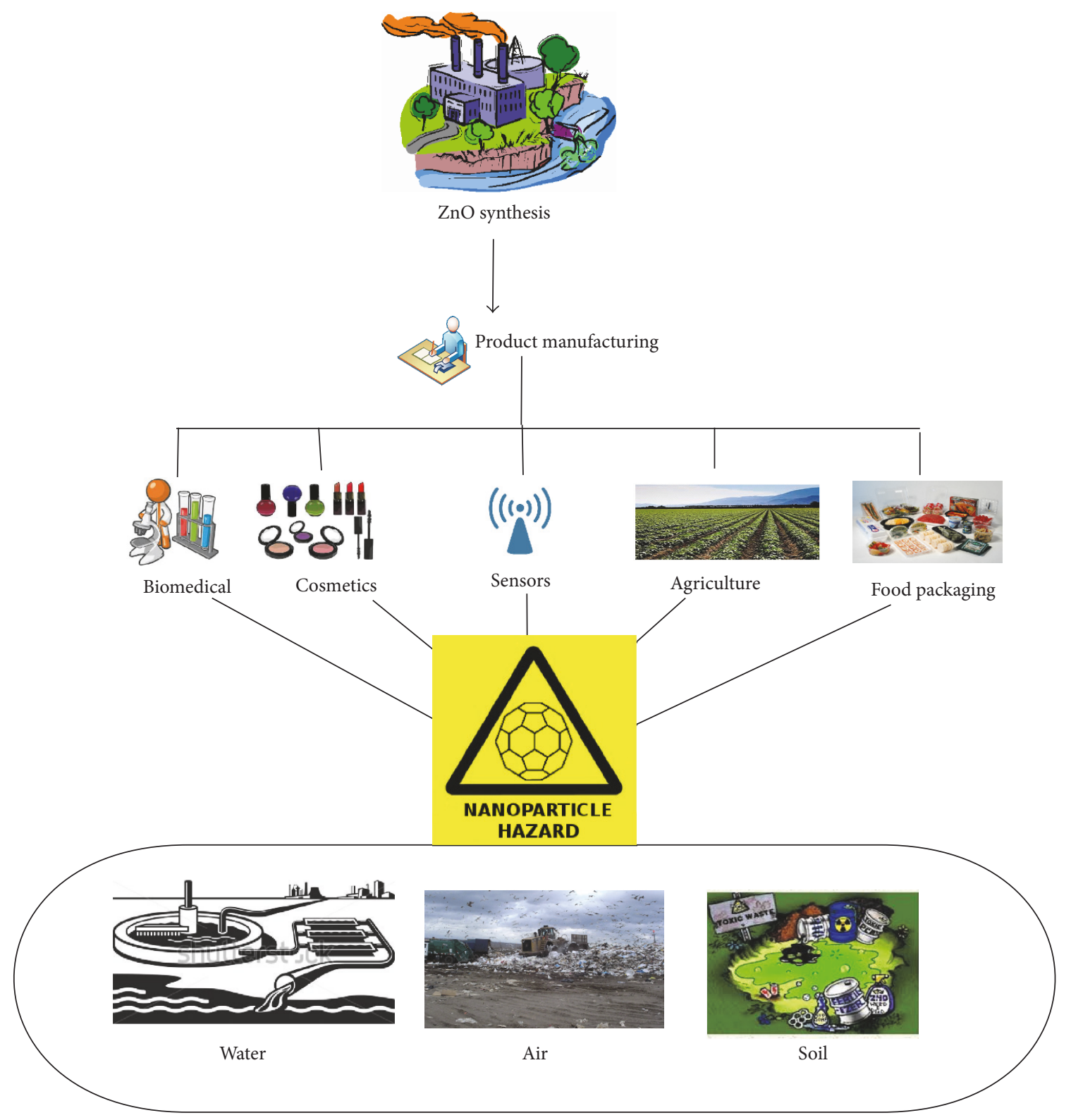

FIGURE 4: Environmental pollution from industrial scale production of $\mathrm{ZnO}$ nanoparticles.

\section{Conclusion and Future Prospects}

Referring to the varied and widespread use of $\mathrm{ZnO}$ in research and industry, it is inevitable to clearly understand the whole life cycle of the $\mathrm{ZnO}$, from raw materials, synthesis, and applications because of lack of data. Further, these particles have altogether different properties from their parent bulk materials. Despite their proven utilities and benefits, still, there are apprehensions about their environmental impacts (Figure 4), as we are still copping with the outcomes of the industrial revolution, although, with a delay of almost fifty years, scientists are able to comprehend the environmental implications of the traditional pollutants created by anthropogenic activities. However, full understanding does not mean that we have successfully dealt with them. Nowadays, with the advancement of science and technology, we are entering in an era of nanomaterials that have rendered unlimited services due to their unique size and shape. Like industrial revolution, the environmental impacts and perils of these synthetic nanoparticles, pollutants emerging from their whole life cycle and potential hazards to biological systems (animals and plants), are least bothering. So far, the fate and distribution of $\mathrm{ZnO}$ pollution have been studied in mammalian models $[167,168]$. However, the question of whether nanoparticles could have a negative/positive biological impact on exposed plants and other organisms is unclear as only few studies are published till date that have revealed variable and, in some cases, conflicting results. Also, there is a lack of regulations for the synthesis, manipulation, and disposal of engineered NPs and as a result these NPs in the environment are being accumulated. Nanoindustry has established itself as a viable substitute of traditional industrial 
processes. A large number of synthetic techniques have been used to get cheaper raw materials $(\mathrm{ZnO} N P)$ and to get maximum yield. Thus, that it may provide a milestone to the researchers to overcome the loop holes of the process.

Chemical synthesis as evident from the name relies on intensive consumption of the chemicals, which are exhausted to the environment as waste material contributing to anthropogenic waste. Techniques employed for the chemical synthesis have their own limitations and drawbacks which can be dealt with green synthesis (plants, microbes, and waste) of $\mathrm{ZnO}$, which offers a relatively pollution free mechanism but optimization of reaction conditions to get higher yield, desired characteristics, and instability put a limitation on its use. It is unpredictable to gauge stability of biosynthesized $\mathrm{ZnO}$ which may otherwise cause serious damage to biological systems. Thus, there is a need to devise and optimize reaction mechanism and techniques for both chemical and green synthesis.

Further, most of the chemicals used in synthetic processes of $\mathrm{ZnO}$ are present in hazardous chemical list and maximum exhaustible limits in environment is well defined in most countries. However, we still need to define these limitations in case of nanopollutants exhausted from the nanoindustry. There is an utter requirement to perform environmental risk assessment in order to estimate the threat posed by $\mathrm{ZnO}$. Also, simulation models should be developed to sketch an analogy between the increasing utility, amount of $\mathrm{ZnO}$ synthesized, and pollutants exhausted during these activities.

\section{Conflicts of Interest}

The authors declare no conflicts of interest.

\section{References}

[1] W. W. Adams and R. H. Baughman, "Richard E. Smalley (1943-2005)," Science, vol. 310, no. 5756, p. 1916, 2005.

[2] M. Nasrollahzadeh and S. Mohammad Sajadi, "Green synthesis of copper nanoparticles using Ginkgo biloba L. leaf extract and their catalytic activity for the Huisgen [3+2] cycloaddition of azides and alkynes at room temperature," Journal of Colloid and Interface Science, vol. 457, pp. 141-147, 2015.

[3] S. Sabir, M. Arshad, and S. K. Chaudhari, "Zinc oxide nanoparticles for revolutionizing agriculture: synthesis and applications," The Scientific World Journal, vol. 2014, Article ID 925494, 2014.

[4] X. Wang, Y. Ding, C. J. Summers, and Z. L. Wang, "Large-scale synthesis of six-nanometer-wide $\mathrm{ZnO}$ nanobelts," The Journal of Physical Chemistry B, vol. 108, no. 26, pp. 8773-8777, 2004.

[5] O. Behera, Synthesis and Characterization of ZnO Nanoparticles of Various Sizes and Applications in Biological Systems, National Institute of Technology, Rourkela, India, 2008.

[6] X. Bai, L. Li, H. Liu, L. Tan, T. Liu, and X. Meng, "Solvothermal synthesis of $\mathrm{ZnO}$ nanoparticles and anti-infection application in vivo," ACS Applied Materials and Interfaces, vol. 7, no. 2, pp. 1308-1317, 2015.

[7] Ü. Özgür, Y. I. Alivov, C. Liu et al., "A comprehensive review of ZnO materials and devices," Journal of Applied Physics, vol. 98, no. 4, Article ID 041301, 2005.
[8] W. J. Jeong, S. K. Kim, and G. C. Park, "Preparation and characteristic of $\mathrm{ZnO}$ thin film with high and low resistivity for an application of solar cell," Thin Solid Films, vol. 506-507, pp. 180$183,2006$.

[9] M. Moritz and M. Geszke-Moritz, "The newest achievements in synthesis, immobilization and practical applications of antibacterial nanoparticles," Chemical Engineering Journal, vol. 228, pp. 596-613, 2013.

[10] K. Rekha, M. Nirmala, M. G. Nair, and A. Anukaliani, "Structural, optical, photocatalytic and antibacterial activity of zinc oxide and manganese doped zinc oxide nanoparticles," Physica B: Condensed Matter, vol. 405, no. 15, pp. 3180-3185, 2010.

[11] S. Nair, A. Sasidharan, V. V. Divya Rani et al., "Role of size scale of $\mathrm{ZnO}$ nanoparticles and microparticles on toxicity toward bacteria and osteoblast cancer cells," Journal of Materials Science: Materials in Medicine, vol. 20, no. 1, pp. S235-S241, 2009.

[12] A. A. Reinert, C. Payne, L. Wang, J. Ciston, Y. Zhu, and P. G. Khalifah, "Synthesis and characterization of visible light absorbing $(\mathrm{GaN}) 1-\mathrm{x}(\mathrm{ZnO}) \mathrm{x}$ semiconductor nanorods," Inorganic Chemistry, vol. 52, no. 15, pp. 8389-8398, 2013.

[13] B. Ludi and M. Niederberger, "Zinc oxide nanoparticles: chemical mechanisms and classical and non-classical crystallization," Dalton Transactions, vol. 42, no. 35, pp. 12554-12568, 2013.

[14] D. Vanmaekelbergh and L. K. Van Vugt, "ZnO nanowire lasers," Nanoscale, vol. 3, no. 7, pp. 2783-2800, 2011.

[15] Z. L. Wang, "Zinc oxide nanostructures: growth, properties and applications," Journal of Physics Condensed Matter, vol. 16, no. 25, pp. R829-R858, 2004.

[16] M. J. Osmond and M. J. McCall, "Zinc oxide nanoparticles in modern sunscreens: an analysis of potential exposure and hazard," Nanotoxicology, vol. 4, no. 1, pp. 15-41, 2010.

[17] M. E. Darvin, K. König, M. Kellner-Hoefer et al., "Safety assessment by multiphoton fluorescence/second harmonic generation/hyper-Rayleigh scattering tomography of $\mathrm{ZnO}$ nanoparticles used in cosmetic products," Skin Pharmacology and Physiology, vol. 25, no. 4, pp. 219-226, 2012.

[18] M. E. Darvin, S. Haag, M. Meinke, L. Zastrow, W. Sterry, and J. Lademann, "Radical production by infrared A irradiation in human tissue," Skin Pharmacology and Physiology, vol. 23, no. 1, pp. 40-46, 2010.

[19] M. E. Darvin, S. F. Haag, J. Lademann, L. Zastrow, W. Sterry, and M. C. Meinke, "Formation of free radicals in human skin during irradiation with infrared light," Journal of Investigative Dermatology, vol. 130, no. 2, pp. 629-631, 2010.

[20] B. Baroli, "Penetration of nanoparticles and nanomaterials in the skin: fiction or reality?" Journal of Pharmaceutical Sciences, vol. 99, no. 1, pp. 21-50, 2010.

[21] P.-J. Lu, S.-C. Huang, Y.-P. Chen, L.-C. Chiueh, and D. Y.-C. Shih, "Analysis of titanium dioxide and zinc oxide nanoparticles in cosmetics," Journal of Food and Drug Analysis, vol. 23, no. 3, pp. 587-594, 2015.

[22] P. Singh and A. Nanda, "Enhanced sun protection of nano-sized metal oxide particles over conventional metal oxide particles: an in vitro comparative study,' International Journal of Cosmetic Science, vol. 36, no. 3, pp. 273-283, 2014.

[23] Y. Zhang, T. R. Nayak, H. Hong, and W. Cai, "Biomedical applications of zinc oxide nanomaterials," Current Molecular Medicine, vol. 13, no. 10, pp. 1633-1645, 2013.

[24] L. Nie, L. Gao, P. Feng et al., "Three-dimensional functionalized tetrapodlike $\mathrm{ZnO}$ nanostructures for plasmid DNA delivery," Small, vol. 2, no. 5, pp. 621-625, 2006. 
[25] L. Nie, L. Gao, X. Yan, and T. Wang, "Functionalized tetrapodlike $\mathrm{ZnO}$ nanostructures for plasmid DNA purification, polymerase chain reaction and delivery," Nanotechnology, vol. 18, no. 1, Article ID 015101, 2007.

[26] A. Umar, M. M. Rahman, M. Vaseem, and Y.-B. Hahn, "Ultrasensitive cholesterol biosensor based on low-temperature grown $\mathrm{ZnO}$ nanoparticles," Electrochemistry Communications, vol. 11, no. 1, pp. 118-121, 2009.

[27] J. Liu, C. Guo, C. M. Li et al., "Carbon-decorated $\mathrm{ZnO}$ nanowire array: a novel platform for direct electrochemistry of enzymes and biosensing applications," Electrochemistry Communications, vol. 11, no. 1, pp. 202-205, 2009.

[28] A. S. Kazemi, R. Afzalzadeh, and M. Abadyan, "ZnO nanoparticles as ethanol gas sensors and the effective parameters on their performance," Journal of Materials Science and Technology, vol. 29, no. 5, pp. 393-400, 2013.

[29] X. Liu, N. Chen, X. Xing et al., "A high-performance n-butanol gas sensor based on $\mathrm{ZnO}$ nanoparticles synthesized by a lowtemperature solvothermal route," RSC Advances, vol. 5, no. 67, pp. 54372-54378, 2015.

[30] C. Parisi, M. Vigani, and E. Rodríguez-Cerezo, "Agricultural nanotechnologies: what are the current possibilities?" Nano Today, vol. 10, no. 2, pp. 124-127, 2015.

[31] P. Bedi and A. Kaur, "An overview on uses of zinc oxide nanoparticles," World Journal of Pharmacy and Pharmaceutical Sciences, vol. 4, no. 12, pp. 1177-1196, 2015.

[32] M. Taheri, H. A. Qarache, A. A. Qarache, and M. Yoosefi, “The effects of zinc-oxide nanoparticles on growth parameters of corn (SC704)," STEM Fellowship Journal, vol. 1, no. 2, pp. 17-20, 2015.

[33] L. R. Khot, S. Sankaran, J. M. Maja, R. Ehsani, and E. W. Schuster, "Applications of nanomaterials in agricultural production and crop protection: a review," Crop Protection, vol. 35, pp. 6470, 2012.

[34] Q. Chaudhry, M. Scotter, J. Blackburn et al., "Applications and implications of nanotechnologies for the food sector," Food Additives and Contaminants. Part A, vol. 25, no. 3, pp. 241-258, 2008.

[35] A. Emamifar, "Applications of antimicrobial polymer nanocomposites in food packaging," in Advances in Nanocomposite Technology, A. Hashim, Ed., chapter 13, InTech, Rijeka, Croatia, 2011.

[36] P. J. P. Espitia, N. D. F. F. Soares, J. S. dos Reis Coimbra, N. J. de Andrade, R. S. Cruz, and E. A. A. Medeiros, "Zinc oxide nanoparticles: synthesis, antimicrobial activity and food packaging applications," Food and Bioprocess Technology, vol. 5, no. 5, pp. 1447-1464, 2012.

[37] X. H. Li, Y. G. Xing, W. L. Li, Y. H. Jiang, and Y. L. Ding, "Antibacterial and physical properties of poly(vinyl chloride)based film coated with $\mathrm{ZnO}$ nanoparticles," Food Science and Technology International, vol. 16, no. 3, pp. 225-232, 2010.

[38] F. S.-S. Chien, C.-R. Wang, Y.-L. Chan, H.-L. Lin, M.-H. Chen, and R.-J. Wu, "Fast-response ozone sensor with $\mathrm{ZnO}$ nanorods grown by chemical vapor deposition," Sensors and Actuators, B: Chemical, vol. 144, no. 1, pp. 120-125, 2010.

[39] P. J. P. Espitia, N. D. F. F. Soares, J. S. D. R. Coimbra, N. J. de Andrade, R. S. Cruz, and E. A. A. Medeiros, "Zinc oxide nanoparticles: synthesis, antimicrobial activity and food packaging applications," Food and Bioprocess Technology, vol. 5, no. 5, pp. 1447-1464, 2012.

[40] W. H. Elmer and J. C. White, "The use of metallic oxide nanoparticles to enhance growth of tomatoes and eggplants in disease infested soil or soilless medium," Environmental Science: Nano, vol. 3, no. 5, pp. 1072-1079, 2016.

[41] N. Milani, M. J. McLaughlin, S. P. Stacey et al., "Dissolution kinetics of macronutrient fertilizers coated with manufactured zinc oxide nanoparticles," Journal of Agricultural and Food Chemistry, vol. 60, no. 16, pp. 3991-3998, 2012.

[42] A. V. Zvyagin, X. Zhao, A. Gierden, W. Sanchez, J. A. Ross, and M. S. Roberts, "Imaging of zinc oxide nanoparticle penetration in human skin in vitro and in vivo," Journal of Biomedical Optics, vol. 13, no. 6, Article ID 064031, 2008.

[43] A. V. Kachynski, A. N. Kuzmin, M. Nyk, I. Roy, and P. N. Prasad, "Zinc oxide nanocrystals for nonresonant nonlinear optical microscopy in biology and medicine," The Journal of Physical Chemistry C, vol. 112, no. 29, pp. 10721-10724, 2008.

[44] K. Vanheusden, W. L. Warren, C. H. Seager, D. R. Tallant, J. A. Voigt, and B. E. Gnade, "Mechanisms behind green photoluminescence in $\mathrm{ZnO}$ phosphor powders," Journal of Applied Physics, vol. 79, no. 10, pp. 7983-7990, 1996.

[45] L. Tian, B. Lin, L. Wu et al., "Neurotoxicity induced by zinc oxide nanoparticles: age-related differences and interaction," Scientific Reports, vol. 5, Article ID 16117, 2015.

[46] E. E. Fröhlich and E. Fröhlich, "Cytotoxicity of nanoparticles contained in food on intestinal cells and the gut microbiota," International Journal of Molecular Sciences, vol. 17, no. 4, article 509, 2016.

[47] W. Chen, Y. Cheng, N. Hsieh et al., "Physiologically based pharmacokinetic modeling of zinc oxide nanoparticles and zinc nitrate in mice," International Journal of Nanomedicine, vol. 10, no. 1, pp. 6277-6292, 2015.

[48] R. J. Vandebriel and W. H. De Jong, "A review of mammalian toxicity of $\mathrm{ZnO}$ nanoparticles," Nanotechnology, Science and Applications, vol. 5, no. 1, pp. 61-71, 2012.

[49] E. E. Connor, J. Mwamuka, A. Gole, C. J. Murphy, and M. D. Wyatt, "Gold nanoparticles are taken up by human cells but do not cause acute cytotoxicity," Small, vol. 1, no. 3, pp. 325-327, 2005.

[50] O. Bondarenko, K. Juganson, A. Ivask, K. Kasemets, M. Mortimer, and $\mathrm{A}$. Kahru, "Toxicity of $\mathrm{Ag}, \mathrm{CuO}$ and $\mathrm{ZnO}$ nanoparticles to selected environmentally relevant test organisms and mammalian cells in vitro: a critical review," Archives of Toxicology, vol. 87, no. 7, pp. 1181-1200, 2013.

[51] J. Liu, X. Feng, L. Wei, L. Chen, B. Song, and L. Shao, "The toxicology of ion-shedding zinc oxide nanoparticles," Critical Reviews in Toxicology, vol. 46, no. 4, pp. 348-384, 2016.

[52] H. Wang, D. Wingett, M. H. Engelhard et al., "Fluorescent dye encapsulated $\mathrm{ZnO}$ particles with cell-specific toxicity for potential use in biomedical applications," Journal of Materials Science: Materials in Medicine, vol. 20, no. 1, pp. 11-22, 2009.

[53] Q. Yuan, S. Hein, and R. D. K. Misra, "New generation of chitosan-encapsulated $\mathrm{ZnO}$ quantum dots loaded with drug: synthesis, characterization and in vitro drug delivery response," Acta Biomaterialia, vol. 6, no. 7, pp. 2732-2739, 2010.

[54] J. W. Rasmussen, E. Martinez, P. Louka, and D. G. Wingett, "Zinc oxide nanoparticles for selective destruction of tumor cells and potential for drug delivery applications," Expert Opinion on Drug Delivery, vol. 7, no. 9, pp. 1063-1077, 2010.

[55] M. Premanathan, K. Karthikeyan, K. Jeyasubramanian, and G. Manivannan, "Selective toxicity of $\mathrm{ZnO}$ nanoparticles toward Gram-positive bacteria and cancer cells by apoptosis through lipid peroxidation," Nanomedicine: Nanotechnology, Biology, and Medicine, vol. 7, no. 2, pp. 184-192, 2011. 
[56] F. Muhammad, M. Guo, W. Qi et al., "PH-triggered controlled drug release from mesoporous silica nanoparticles via intracelluar dissolution of $\mathrm{ZnO}$ nanolids," Journal of the American Chemical Society, vol. 133, no. 23, pp. 8778-8781, 2011.

[57] D. Guo, C. Wu, H. Jiang, Q. Li, X. Wang, and B. Chen, "Synergistic cytotoxic effect of different sized $\mathrm{ZnO}$ nanoparticles and daunorubicin against leukemia cancer cells under UV irradiation," Journal of Photochemistry and Photobiology B: Biology, vol. 93, no. 3, pp. 119-126, 2008.

[58] G. Lin, H. Zhang, and L. Huang, "Smart polymeric nanoparticles for cancer gene delivery," Molecular Pharmaceutics, vol. 12, no. 2, pp. 314-321, 2015.

[59] J. Liu, X. Ma, S. Jin et al., "Zinc oxide nanoparticles as adjuvant to facilitate doxorubicin intracellular accumulation and visualize $\mathrm{pH}$-responsive release for overcoming drug resistance," Molecular Pharmaceutics, vol. 13, no. 5, pp. 1723-1730, 2016.

[60] N. V. Mantzaris, "Liquid-phase synthesis of nanoparticles: particle size distribution dynamics and control," Chemical Engineering Science, vol. 60, no. 17, pp. 4749-4770, 2005.

[61] M. F. Khan, A. H. Ansari, M. Hameedullah et al., "Sol-gel synthesis of thorn-like $\mathrm{ZnO}$ nanoparticles endorsing mechanical stirring effect and their antimicrobial activities: potential role as nano-Antibiotics," Scientific Reports, vol. 6, Article ID 27689, 2016.

[62] B. Gersten, "Solvothermal synthesis of nanoparticles," Chemfiles, vol. 5, pp. 11-12, 2005.

[63] P. Rai, W.-K. Kwak, and Y.-T. Yu, "Solvothermal synthesis of $\mathrm{ZnO}$ nanostructures and their morphology-dependent gassensing properties," ACS Applied Materials and Interfaces, vol. 5, no. 8, pp. 3026-3032, 2013.

[64] F. Iskandar, "Nanoparticle processing for optical applications-a review," Advanced Powder Technology, vol. 20, no. 4, pp. 283-292, 2009.

[65] Y. R. Uhm, B. S. Han, M. K. Lee, S. J. Hong, and C. K. Rhee, "Synthesis and characterization of nanoparticles of $\mathrm{ZnO}$ by levitational gas condensation," Materials Science and Engineering A, vol. 448-451, pp. 813-816, 2007.

[66] N. Salah, S. S. Habib, Z. H. Khan et al., "High-energy ball milling technique for $\mathrm{ZnO}$ nanoparticles as antibacterial material," International Journal of Nanomedicine, vol. 6, pp. 863-869, 2011.

[67] R. A. Ismail, A. K. Ali, M. M. Ismail, and K. I. Hassoon, "Preparation and characterization of colloidal $\mathrm{ZnO}$ nanoparticles using nanosecond laser ablation in water," Applied Nanoscience, vol. 1, no. 1, pp. 45-49, 2011.

[68] O. Tigli and J. Juhala, "ZnO nanowire growth by physical vapor deposition," in Proceedings of the 11th IEEE International Conference on Nanotechnology (NANO '11), pp. 608-611, Portland, Ore, USA, August 2011.

[69] Z.-U. Mashwani, M. A. Khan, T. Khan, and A. Nadhman, "Applications of plant terpenoids in the synthesis of colloidal silver nanoparticles," Advances in Colloid and Interface Science, vol. 234, pp. 132-141, 2016.

[70] Z.-U.-R. Mashwani, T. Khan, M. A. Khan, and A. Nadhman, "Synthesis in plants and plant extracts of silver nanoparticles with potent antimicrobial properties: current status and future prospects," Applied Microbiology and Biotechnology, vol. 99, no. 23, pp. 9923-9934, 2015.

[71] N. A. N. Mohamad, N. A. Arham, J. Jai, and A. Hadi, "Plant extract as reducing agent in synthesis of metallic nanoparticles: a review," Advanced Materials Research, vol. 832, pp. 350-355, 2014.
[72] V. V. Makarov, A. J. Love, O. V. Sinitsyna et al., “'Green’ nanotechnologies: synthesis of metal nanoparticles using plants," Acta Naturae, vol. 6, no. 1, pp. 35-44, 2014.

[73] A. G. Ingale and A. N. Chaudhari, "Biogenic synthesis of nanoparticles and potential applications: an eco-friendly approach," Journal of Nanomedicine and Nanotechnology, vol. 4, no. 2, 2013.

[74] T. Klaus-Joerger, R. Joergere, E. Olsson, and C. Granqvist, "Bacteria as workers in the living factory: metal-accumulating bacteria and their potential for materials science," Trends in Biotechnology, vol. 19, no. 1, pp. 15-20, 2001.

[75] A. Yadav, K. Kon, G. Kratosova, N. Duran, A. P. Ingle, and M. Rai, "Fungi as an efficient mycosystem for the synthesis of metal nanoparticles: progress and key aspects of research," Biotechnology Letters, vol. 37, no. 11, pp. 2099-2120, 2015.

[76] N. Jain, A. Bhargava, J. C. Tarafdar, S. K. Singh, and J. Panwar, "A biomimetic approach towards synthesis of zinc oxide nanoparticles," Applied Microbiology and Biotechnology, vol. 97, no. 2, pp. 859-869, 2013.

[77] S. Jacob, R. Bharathkumar, and G. Ashwathram, "Aspergillus niger mediated synthesis of $\mathrm{ZnO}$ nanoparticles and their antimicrobial and in vitro anticancerous activity," World Journal of Pharmaceutical Sciences, vol. 3, no. 2, pp. 3044-3054, 2014.

[78] G. Baskar, J. Chandhuru, K. S. Fahad, and A. Praveen, "Mycological synthesis, characterization and antifungal activity of zinc oxide nanoparticles," Asian Journal of Pharmacy and Technology, vol. 3, no. 4, pp. 142-146, 2013.

[79] C. Jayaseelan, A. A. Rahuman, A. V. Kirthi et al., "Novel microbial route to synthesize $\mathrm{ZnO}$ nanoparticles using Aeromonas hydrophila and their activity against pathogenic bacteria and fungi," Spectrochimica Acta Part A: Molecular and Biomolecular Spectroscopy, vol. 90, pp. 78-84, 2012.

[80] M. Z. Hussein, W. H. W. N. Azmin, M. Mustafa, and A. H. Yahaya, "Bacillus cereus as a biotemplating agent for the synthesis of zinc oxide with raspberry- and plate-like structures," Journal of Inorganic Biochemistry, vol. 103, no. 8, pp. 1145-1150, 2009.

[81] R. S. Scott, S. R. Frame, P. E. Ross, S. E. Loveless, and G. L. Kennedy, "Inhalation toxicity of 1,3-propanediol in the rat," Inhalation Toxicology, vol. 17, no. 9, pp. 487-493, 2008.

[82] S. Azizi, M. B. Ahmad, F. Namvar, and R. Mohamad, "Green biosynthesis and characterization of zinc oxide nanoparticles using brown marine macroalga Sargassum muticum aqueous extract,” Materials Letters, vol. 116, pp. 275-277, 2014.

[83] A. K. Jha and K. Prasad, "Synthesis of $\mathrm{ZnO}$ nanoparticles from goat slaughter waste for environmental protection," International Journal of Current Engineering and Technology, vol. 6, no. 1, pp. 147-151, 2016.

[84] R. Dobrucka and J. Długaszewska, "Biosynthesis and antibacterial activity of $\mathrm{ZnO}$ nanoparticles using Trifolium pratense flower extract," Saudi Journal of Biological Sciences, vol. 23, no. 4, pp. 517-523, 2016.

[85] V. Mishra and R. Sharma, "Green synthesis of zinc oxide nanoparticles using fresh peels extract of Punica granatum and its antimicrobial activities," International Journal of Pharma Research and Health Sciences, vol. 3, no. 3, pp. 694-699, 2015.

[86] C. Tamuly, I. Saikia, M. Hazarika et al., "Bio-derived $\mathrm{ZnO}$ nanoflower: a highly efficient catalyst for the synthesis of chalcone derivatives," RSC Advances, vol. 5, no. 12, pp. 8604-8608, 2015.

[87] B. Kumar, K. Smita, L. Cumbal, and A. Debut, "Green approach for fabrication and applications of zinc oxide nanoparticles," 
Bioinorganic Chemistry and Applications, vol. 2014, Article ID 523869, 7 pages, 2014.

[88] F. Davar, A. Majedi, and A. Mirzaei, "Green synthesis of $\mathrm{ZnO}$ nanoparticles and its application in the degradation of some dyes," Journal of the American Ceramic Society, vol. 98, no. 6, pp. 1739-1746, 2015.

[89] Z.-R. Tang, X. Yin, Y. Zhang, and Y.-J. Xu, "One-pot, high-yield synthesis of one-dimensional $\mathrm{ZnO}$ nanorods with well-defined morphology as a highly selective photocatalyst," RSC Advances, vol. 3, no. 17, pp. 5956-5965, 2013.

[90] Z. L. Wang, "Splendid one-dimensional nanostructures of zinc oxide: a new nanomaterial family for nanotechnology," ACS Nano, vol. 2, no. 10, pp. 1987-1992, 2008.

[91] Y. Lu, L. Wang, D. Wang, T. Xie, L. Chen, and Y. Lin, "A comparative study on plate-like and flower-like $\mathrm{ZnO}$ nanocrystals surface photovoltage property and photocatalytic activity," Materials Chemistry and Physics, vol. 129, no. 1-2, pp. 281-287, 2011.

[92] J. Liu, Z.-Y. Hu, Y. Peng et al., “2D ZnO mesoporous singlecrystal nanosheets with exposed 0001 polar facets for the depollution of cationic dye molecules by highly selective adsorption and photocatalytic decomposition," Applied Catalysis B: Environmental, vol. 181, pp. 138-145, 2016.

[93] W. S. Chiu, P. S. Khiew, M. Cloke et al., "Photocatalytic study of two-dimensional $\mathrm{ZnO}$ nanopellets in the decomposition of methylene blue," Chemical Engineering Journal, vol. 158, no. 2, pp. 345-352, 2010.

[94] Q. Xie, Z. Dai, J. Liang, L. Xu, W. Yu, and Y. Qian, "Synthesis of $\mathrm{ZnO}$ three-dimensional architectures and their optical properties," Solid State Communications, vol. 136, no. 5, pp. 304-307, 2005.

[95] P. Raveendran, J. Fu, and S. L. Wallen, "Completely "green" synthesis and stabilization of metal nanoparticles," Journal of the American Chemical Society, vol. 125, no. 46, pp. 13940-13941, 2003.

[96] E. E. L. Tanner, K. Tschulik, R. Tahany, K. Jurkschat, C. Batchelor-McAuley, and R. G. Compton, "Nanoparticle capping agent dynamics and electron transfer: polymer-gated oxidation of silver nanoparticles," The Journal of Physical Chemistry C, vol. 119, no. 32, pp. 18808-18815, 2015.

[97] Z. Zhou, J. Son, B. Harper, Z. Zhou, and S. Harper, "Influence of surface chemical properties on the toxicity of engineered zinc oxide nanoparticles to embryonic zebrafish," Beilstein Journal of Nanotechnology, vol. 6, no. 1, pp. 1568-1579, 2015.

[98] Y. Y. Liu, I. Schmeltz, and D. Hoffmann, "Chemical studies on tobacco smoke. Quantitative analysis of hydrazine in tobacco and cigarette smoke," Analytical Chemistry, vol. 46, no. 7, pp. 885-889, 1974.

[99] G. Lunn, E. B. Sansone, and L. K. Keefer, "Notes. Reductive destruction of hydrazines as an approach to hazard control," Environmental Science and Technology, vol. 17, no. 4, pp. 240243, 1983.

[100] R. Rajendram and V. R. Preedy, "Effect of alcohol consumption on the gut," Digestive Diseases, vol. 23, no. 3-4, pp. 214-221, 2006.

[101] R. B. Forney and R. N. Harger, “Toxicology of ethanol," Annual Review of Pharmacology, vol. 9, no. 1, pp. 379-392, 1969.

[102] A. K. Mehta and M. K. Ticku, "Ethanol potentiation of GABAergic transmission in cultured spinal cord neurons involves gamma-aminobutyric acidA-gated chloride channels," Journal of Pharmacology and Experimental Therapeutics, vol. 246, no. 2, pp. 558-564, 1988.
[103] D. Jacobsen and K. E. McMartin, "Methanol and ethylene glycol poisonings," Medical Toxicology, vol. 1, no. 5, pp. 309-334, 1986.

[104] Health, Safety and Environment, Occupational Safety Unit UoR. Environmental Health \& Safety Occupational Safety Unit 2012.

[105] A. Khorsand Zak, W. H. A. Majid, H. Z. Wang, R. Yousefi, A. Moradi Golsheikh, and Z. F. Ren, "Sonochemical synthesis of hierarchical ZnO nanostructures," Ultrasonics Sonochemistry, vol. 20, no. 1, pp. 395-400, 2013.

[106] H. Xu, B. W. Zeiger, and K. S. Suslick, "Sonochemical synthesis of nanomaterials," Chemical Society Reviews, vol. 42, no. 7, pp. 2555-2567, 2013.

[107] H.-M. Xiong, D. G. Shchukin, H. Möhwald, Y. Xu, and Y.Y. Xia, "Sonochemical synthesis of highly luminescent zinc oxide nanoparticles doped with magnesium(II)," Angewandte Chemie-International Edition, vol. 48, no. 15, pp. 2727-2731, 2009.

[108] A. E. Kandjani, M. F. Tabriz, and B. Pourabbas, "Sonochemical synthesis of $\mathrm{ZnO}$ nanoparticles: the effect of temperature and sonication power," Materials Research Bulletin, vol. 43, no. 3, pp. 645-654, 2008.

[109] I. A. Siddiquey, T. Furusawa, M. Sato, N. M. Bahadur, M. Mahbubul Alam, and N. Suzuki, "Sonochemical synthesis, photocatalytic activity and optical properties of silica coated $\mathrm{ZnO}$ nanoparticles," Ultrasonics Sonochemistry, vol. 19, no. 4, pp. 750755, 2012.

[110] A. Askarinejad, M. A. Alavi, and A. Morsali, "Sonochemically assisted synthesis of $\mathrm{ZnO}$ nanoparticles: a novel direct method," Iranian Journal of Chemistry and Chemical Engineering, vol. 30, no. 3, pp. 75-81, 2011.

[111] C. Pholnak, C. Sirisathitkul, S. Danworaphong, and D. J. Harding, "Sonochemical synthesis of zinc oxide nanoparticles using an ultrasonic homogenizer," Ferroelectrics, vol. 455, no. 1, pp. 1520, 2013.

[112] J. S. Taurozzi, V. A. Hackley, and M. R. Wiesner, "Ultrasonic dispersion of nanoparticles for environmental, health and safety assessment-issues and recommendations," Nanotoxicology, vol. 5, no. 4, pp. 711-729, 2011.

[113] J. E. Edinger, D. K. Brady, and J. C. Geyer, "Heat exchange and transport in the environment," Tech. Rep. 14, Johns Hopkins University, Department of Geography and Environmental Engineering, Baltimore, Md, USA, 1974.

[114] J. Soni and A. Koser, "Synthesis of $\mathrm{ZnO}$ nanoparticle using different concentration of capping agent," International Journal of Technology Innovations and Research, vol. 16, pp. 1-7, 2015.

[115] S. B. Rana, P. Singh, A. K. Sharma, A. W. Carbonari, and R. Dogra, "Synthesis and characterization of pure and doped $\mathrm{ZnO}$ nanoparticles," Journal of Optoelectronics and Advanced Materials, vol. 12, no. 2, pp. 257-261, 2010.

[116] Y. T. Prabhu, K. V. Rao, V. S. S. Kumar, and B. S. Kumari, "Synthesis of $\mathrm{ZnO}$ nanoparticles by a novel surfactant assisted amine combustion method," Advances in Nanoparticles, vol. 2, no. 1, pp. 45-50, 2013.

[117] H. Chang and M.-H. Tsai, "Synthesis and characterization of $\mathrm{ZnO}$ nanoparticles having prism shape by a novel gas condensation process," Reviews on Advanced Materials Science, vol. 18, no. 8, pp. 734-743, 2008.

[118] J. Wen, Y. Hu, K. Zhu, Y. Li, and J. Song, "High-temperaturemixing hydrothermal synthesis of $\mathrm{ZnO}$ nanocrystals with wide growth window," Current Applied Physics, vol. 14, no. 3, pp. 359$365,2014$. 
[119] B. Åkesson, M. Bengtsson, and I. Florén, "Visual disturbances after industrial triethylamine exposure," International Archives of Occupational and Environmental Health, vol. 57, no. 4, pp. 297-302, 1986.

[120] D. Ju, H. Xu, Z. Qiu, J. Guo, J. Zhang, and B. Cao, "Highly sensitive and selective triethylamine-sensing properties of nanosheets directly grown on ceramic tube by forming $\mathrm{NiO} / \mathrm{ZnO} \mathrm{PN}$ heterojunction," Sensors and Actuators B: Chemical, vol. 200, pp. 288-296, 2014.

[121] M. El-Kemary, H. El-Shamy, and I. El-Mehasseb, "Photocatalytic degradation of ciprofloxacin drug in water using $\mathrm{ZnO}$ nanoparticles," Journal of Luminescence, vol. 130, no. 12, pp. 2327-2331, 2010.

[122] M. Sato, H. Harada, S. Morito et al., "Preparation, characterization and properties of novel covalently surface-functionalized zinc oxide nanoparticles," Applied Surface Science, vol. 256, no. 14, pp. 4497-4501, 2010.

[123] M. F. Cury-Boaventura, C. Pompéia, and R. Curi, "Comparative toxicity of oleic acid and linoleic acid on Raji cells," Nutrition, vol. 21, no. 3, pp. 395-405, 2005.

[124] X. Tang, E. S. G. Choo, N. Li, J. Ding, and J. Xue, "One-pot synthesis of water-stable $\mathrm{ZnO}$ nanoparticles via a polyol hydrolysis route and their cell labeling applications," Langmuir, vol. 25, no. 9, pp. 5271-5275, 2009.

[125] A. Mclaren, T. Valdes-Solis, G. Li, and S. C. Tsang, "Shape and size effects of $\mathrm{ZnO}$ nanocrystals on photocatalytic activity," Journal of the American Chemical Society, vol. 131, no. 35, pp. 12540-12541, 2009.

[126] Y. Gong, T. Andelman, G. F. Neumark, S. O’Brien, and I. L. Kuskovsky, "Origin of defect-related green emission from $\mathrm{ZnO}$ nanoparticles: effect of surface modification," Nanoscale Research Letters, vol. 2, no. 6, pp. 297-302, 2007.

[127] O. V. Singh, Bio-Nanoparticles: Biosynthesis and Sustainable Biotechnological Implications, John Wiley \& Sons, 2015.

[128] R. K. Dutta, B. P. Nenavathu, M. K. Gangishetty, and A. V. R. Reddy, "Studies on antibacterial activity of $\mathrm{ZnO}$ nanoparticles by ROS induced lipid peroxidation," Colloids and Surfaces B: Biointerfaces, vol. 94, pp. 143-150, 2012.

[129] R. Tripathi, A. Kumar, C. Bharti, and T. P. Sinha, "Dielectric relaxation of $\mathrm{ZnO}$ nanostructure synthesized by soft chemical method," Current Applied Physics, vol. 10, no. 2, pp. 676-681, 2010.

[130] A. Aboulaich, L. Balan, J. Ghanbaja, G. Medjahdi, C. Merlin, and R. Schneider, "Aqueous route to biocompatible $\mathrm{ZnSe:Mn/ZnO}$ core/shell quantum dots using 1-thioglycerol as stabilizer," Chemistry of Materials, vol. 23, no. 16, pp. 3706-3713, 2011.

[131] J. R. Hart, Ethylenediaminetetraacetic Acid and Related Chelating Agents, Ullmann's Encyclopedia of Industrial Chemistry, 2000.

[132] R. Lanigan and T. Yamarik, "Final report on the safety assessment of EDTA, calcium disodium EDTA, diammonium EDTA, dipotassium EDTA, disodium EDTA, TEA-EDTA, tetrasodium EDTA, tripotassium EDTA, trisodium EDTA, HEDTA, and trisodium HEDTA," International Journal of Toxicology, vol. 21, no. 2, pp. 95-142, 2002.

[133] X. Zhao, X. Ren, C. Sun et al., "Morphology evolution at nanoto micro-scale," Functional Materials Letters, vol. 1, no. 3, pp. 167-172, 2008.

[134] P. Chandrasekaran, G. Viruthagiri, and N. Srinivasan, "The effect of various capping agents on the surface modifications of sol-gel synthesised ZnO nanoparticles," Journal of Alloys and Compounds, vol. 540, pp. 89-93, 2012.
[135] M. Ramani, S. Ponnusamy, C. Muthamizhchelvan, J. Cullen, S. Krishnamurthy, and E. Marsili, "Morphology-directed synthesis of $\mathrm{ZnO}$ nanostructures and their antibacterial activity," Colloids and Surfaces B: Biointerfaces, vol. 105, pp. 24-30, 2013.

[136] A. J. P. Graham, “Toxic effects of tetraethylammonium bromide," British Medical Journal, vol. 2, no. 4674, pp. 321-322, 1950.

[137] R.-O. Moussodia, L. Balan, and R. Schneider, "Synthesis and characterization of water-soluble $\mathrm{ZnO}$ quantum dots prepared through PEG-siloxane coating," New Journal of Chemistry, vol. 32, no. 8, pp. 1388-1393, 2008.

[138] D. Verma, A. K. Kole, and P. Kumbhakar, "Red shift of the bandedge photoluminescence emission and effects of annealing and capping agent on structural and optical properties of $\mathrm{ZnO}$ nanoparticles," Journal of Alloys and Compounds, vol. 625, pp. 122-130, 2015.

[139] S. Mallakpour and V. Behranvand, "Surface treatment of nano $\mathrm{ZnO}$ using 3,4,5,6-tetrabromo-N-(4-hydroxy-phenyl) phthalamic acid as novel coupling agent for the preparation of poly(amide-imide)/ZnO nanocomposites," Colloid and Polymer Science, vol. 292, no. 9, pp. 2275-2283, 2014.

[140] D. A. P. Bulla and N. I. Morimoto, "Deposition of thick TEOS PECVD silicon oxide layers for integrated optical waveguide applications," Thin Solid Films, vol. 334, no. 1-2, pp. 60-64, 1998.

[141] L. Y. L. Wu, A. I. Y. Tok, F. Y. C. Boey, X. T. Zeng, and X. $\mathrm{H}$. Zhang, "Chemical synthesis of $\mathrm{ZnO}$ nanocrystals," IEEE Transactions on Nanotechnology, vol. 6, no. 5, pp. 497-503, 2007.

[142] J. Wang, T. Tsuzuki, L. Sun, and X. Wang, "Reverse microemulsion-mediated synthesis of $\mathrm{SiO}_{2}$-coated $\mathrm{ZnO}$ composite nanoparticles: multiple cores with tunable shell thickness," ACS Applied Materials and Interfaces, vol. 2, no. 4, pp. 957-960, 2010.

[143] Z. Cao and Z. Zhang, "Deactivation of photocatalytically active $\mathrm{ZnO}$ nanoparticle and enhancement of its compatibility with organic compounds by surface-capping with organically modified silica," Applied Surface Science, vol. 257, no. 9, pp. 4151-4158, 2011.

[144] H. J. Allen, C. A. Impellitteri, D. A. Macke et al., "Effects from filtration, capping agents, and presence/absence of food on the toxicity of silver nanoparticles to Daphnia magna," Environmental Toxicology and Chemistry, vol. 29, no. 12, pp. 2742-2750, 2010.

[145] M. Sudha, S. Senthilkumar, R. Hariharan, A. Suganthi, and M. Rajarajan, "Synthesis, characterization and study of photocatalytic activity of surface modified $\mathrm{ZnO}$ nanoparticles by PEG capping," Journal of Sol-Gel Science and Technology, vol. 65, no. 3, pp. 301-310, 2013.

[146] L. Sax, "Polyethylene terephthalate May yield endocrine disruptors," Environmental Health Perspectives, vol. 118, no. 4, pp. 445448, 2010.

[147] G. S. Thool, A. K. Singh, R. S. Singh, A. Gupta, and M. A. B. H. Susan, "Facile synthesis of flat crystal $\mathrm{ZnO}$ thin films by solution growth method: a micro-structural investigation," Journal of Saudi Chemical Society, vol. 18, no. 5, pp. 712-721, 2014.

[148] D. Pradhan, Z. Su, S. Sindhwani, J. F. Honek, and K. T. Leung, "Electrochemical growth of $\mathrm{ZnO}$ nanobelt-like structures at $0 \circ \mathrm{c}$ : synthesis, characterization, and in-situ glucose oxidase embedment," Journal of Physical Chemistry C, vol. 115, no. 37, pp. 18149-18156, 2011.

[149] T. Thirugnanam, "Effect of polymers (PEG and PVP) on sol-gel synthesis of microsized zinc oxide," Journal of Nanomaterials, vol. 2013, Article ID 362175, 7 pages, 2013. 
[150] National Toxicology Program, "NTP-CERHR monograph on the potential human reproductive and developmental effects of ethylene glycol," NTP CERHR MON, no. 11, pp. 1-III36, 2004.

[151] J. Sedlák, I. Kuřitka, M. Machovský, P. Šuly, P. Bažant, and T. Sedláček, "Zinc oxide nanoparticles with surface modified by degradation of capping polymers in situ during microwave synthesis," Advanced Powder Technology, vol. 26, no. 4, pp. 1064-1071, 2015.

[152] R. Devaraj, K. Karthikeyan, and K. Jeyasubramanian, "Synthesis and properties of $\mathrm{ZnO}$ nanorods by modified Pechini process," Applied Nanoscience, vol. 3, no. 1, pp. 37-40, 2013.

[153] K. Liu, J.-J. Zhang, F.-F. Cheng, T.-T. Zheng, C. Wang, and J.-J. Zhu, "Green and facile synthesis of highly biocompatible graphene nanosheets and its application for cellular imaging and drug delivery," Journal of Materials Chemistry, vol. 21, no. 32, pp. 12034-12040, 2011.

[154] Y. Tamgadge, K. Patil, and R. Ganorkar, "Synthesis and characterization of gelatin capped Zno nanoparticles," International Journal of Scientific Research, vol. 5, no. 1, article 7, 2016.

[155] S. Shankar, X. Teng, G. Li, and J.-W. Rhim, "Preparation, characterization, and antimicrobial activity of gelatin/ZnO nanocomposite films," Food Hydrocolloids, vol. 45, pp. 264-271, 2015.

[156] C. M. Kelly, C. C. DeMerlis, D. R. Schoneker, and J. F. Borzelleca, "Subchronic toxicity study in rats and genotoxicity tests with polyvinyl alcohol," Food and Chemical Toxicology, vol. 41, no. 5, pp. 719-727, 2003.

[157] C. C. DeMerlis and D. R. Schoneker, "Review of the oral toxicity of polyvinyl alcohol (PVA)," Food and Chemical Toxicology, vol. 41, no. 3, pp. 319-326, 2003.

[158] T. K. Kundu, N. Karak, P. Barik, and S. Saha, "Optical properties of $\mathrm{ZnO}$ nanoparticles prepared by chemical method using poly (vinyl alcohol)(PVA) as capping agent," International Journal of Soft Computing and Engineering, vol. 1, pp. 19-24, 2011.

[159] D. Shao, H. Sun, M. Yu, J. Lian, and S. Sawyer, "Enhanced ultraviolet emission from poly(vinyl alcohol) $\mathrm{ZnO}$ nanoparticles using a SiO2-Au core/shell structure," Nano Letters, vol. 12, no. 11, pp. 5840-5844, 2012.

[160] A. P. Nagvenkar, A. Deokar, I. Perelshtein, and A. Gedanken, "A one-step sonochemical synthesis of stable ZnO-PVA nanocolloid as a potential biocidal agent," Journal of Materials Chemistry B, vol. 4, no. 12, pp. 2124-2132, 2016.

[161] Health UDo, H. Services, N. T. Program, and Reproduction CftEoRtH, NTP-CERHR Monograph on the Potential Human Reproductive and Developmental Effects of Ethylene Glycol, 044481, NIH Publication, 2004.

[162] S. Tachikawa, A. Noguchi, T. Tsuge, M. Hara, O. Odawara, and H. Wada, "Optical properties of $\mathrm{ZnO}$ nanoparticles capped with polymers," Materials, vol. 4, no. 6, pp. 1132-1143, 2011.

[163] G. Bandekar, N. S. Rajurkar, I. S. Mulla, U. P. Mulik, D. P. Amalnerkar, and P. V. Adhyapak, "Synthesis, characterization and photocatalytic activity of PVP stabilized $\mathrm{ZnO}$ and modified ZnO nanostructures," Applied Nanoscience, vol. 4, no. 2, pp. 199-208, 2014.

[164] M. L. Singla, M. M. Shafeeq, and M. Kumar, "Optical characterization of $\mathrm{ZnO}$ nanoparticles capped with various surfactants," Journal of Luminescence, vol. 129, no. 5, pp. 434-438, 2009.

[165] X. Feng, Y. Yan, B. Wan et al., "Enhanced dissolution and transformation of $\mathrm{ZnO}$ nanoparticles: the role of inositol hexakisphosphate," Environmental Science and Technology, vol. 50, no. 11, pp. 5651-5660, 2016.
[166] M. Auffan, J. Rose, M. R. Wiesner, and J.-Y. Bottero, "Chemical stability of metallic nanoparticles: a parameter controlling their potential cellular toxicity in vitro," Environmental Pollution, vol. 157, no. 4, pp. 1127-1133, 2009.

[167] H. Kuang, P. Yang, L. Yang, Z. P. Aguilar, and H. Xu, "Size dependent effect of $\mathrm{ZnO}$ nanoparticles on endoplasmic reticulum stress signaling pathway in murine liver," Journal of Hazardous Materials, vol. 317, pp. 119-126, 2016.

[168] C. Wang, X. Hu, Y. Gao, and Y. Ji, “ZnO nanoparticles treatment induces apoptosis by increasing intracellular ROS levels in LTEP-a-2 cells," BioMed Research International, vol. 2015, Article ID 423287, 9 pages, 2015. 

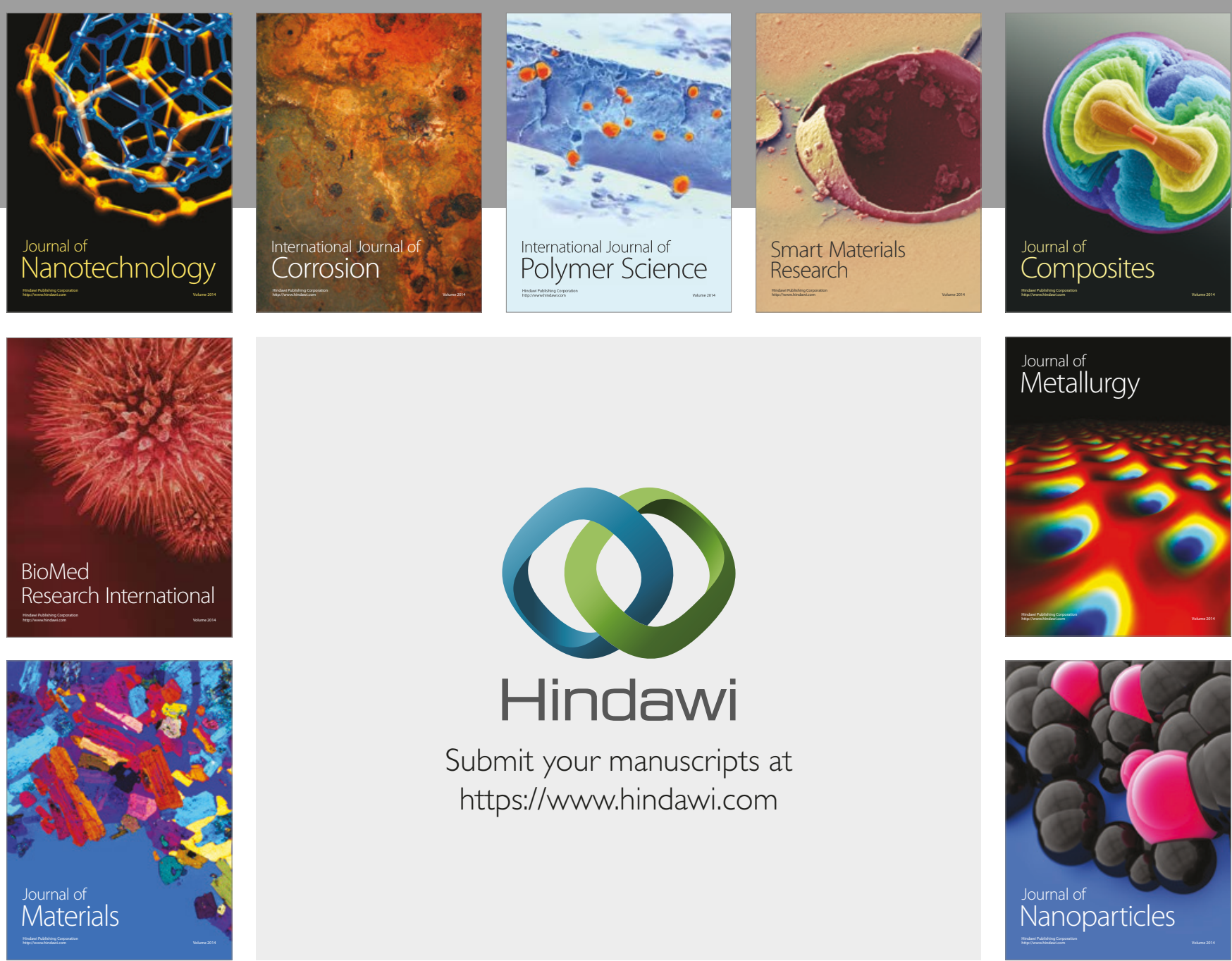

\section{Hindawi}

Submit your manuscripts at

https://www.hindawi.com
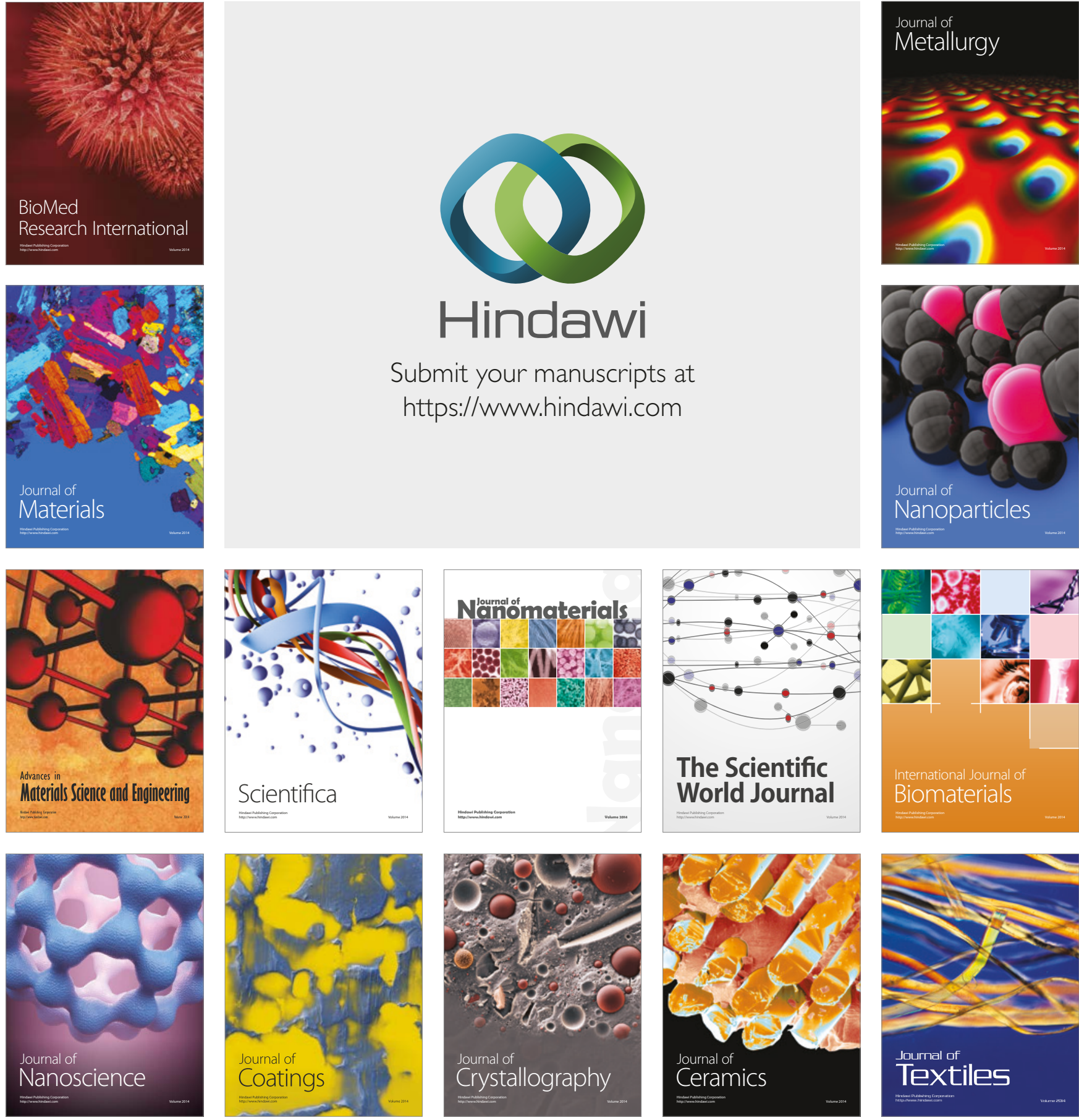

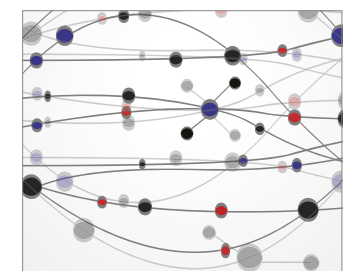

The Scientific World Journal
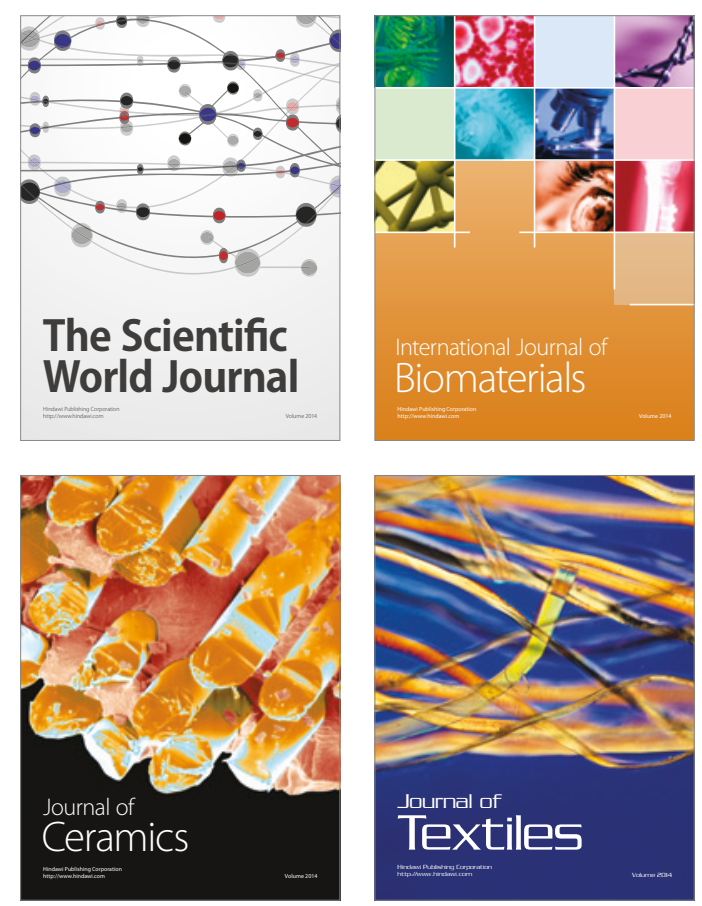